\title{
Monetary policy and stock valuation: Structural VAR identification and size effects
}

\author{
Alexandros Kontonikas ${ }^{\S}$ and Zivile Zekaite
}

\begin{abstract}
This paper examines the relationship between the US monetary policy and stock valuation using a structural VAR framework that allows for the simultaneous interaction between the federal funds rate and stock market developments based on the assumption of long-run monetary neutrality. The results confirm a strong, negative and significant monetary policy tightening effect on real stock prices. Furthermore, we provide evidence consistent with a delayed response of small stocks to monetary policy shocks relative to large stocks.
\end{abstract}

\footnotetext{
$\S$ Corresponding author. Essex Business School, Finance Subject Group, University of Essex, Colchester, CO4 3SQ, UK, a.kontonikas@essex.ac.uk.

* Adam Smith Business School, University of Glasgow, Glasgow, G12 8QQ, UK, z.zekaite.1@ research.gla.ac.uk. We would also like to thank Tom Doan for providing the estimation code and helpful advice.
} 


\section{Introduction}

Finance practitioners and academic researchers generally agree that monetary policy shifts have strong effects on financial markets and that there may be the role for asset prices in the monetary policy reaction function. ${ }^{1}$ The empirical literature investigating the relationship between monetary policy and stock valuation in the United States goes back to 1970 s. $^{2}$ In these early studies it is acknowledged that causality may run in both directions (Cooper, 1974; Smirlock and Yawitz, 1985). Given that stock prices, amongst other asset prices, feature in the monetary policy transmission mechanism, it is important to gain a thorough understanding of how monetary policy interacts with stock market developments (Mishkin, 2001; Bjornland and Jacobsen, 2013). This paper re-examines this relationship at both the market and portfolio level using data on portfolios formed on the basis of firm's size (market value). The empirical framework that we use allows for the short-run interaction between monetary policy and real stock price developments, assuming long-run monetary neutrality.

Monetary policy may affect stock prices through its impact on the expected future net cash flows and the discount rate; the latter being equal to the sum of a risk-free interest rate and a risk premium (Smirlock and Yawitz, 1985; Kontonikas and Kostakis, 2013). According to the traditional interest rate channel, monetary policy tightening lowers the demand for loans due to higher costs of borrowing. In turn, consumption and investment spending decline leading to lower expected future net cash flows and, consequently, to lower current stock prices (Bernanke and Gertler, 1995; Ehrmann and Fratzscher, 2004). The credit channel operates via the impact of monetary policy on the external finance premium (Gertler and Gilchrist, 1994; Bernanke and Gertler, 1995, Kiyotaki and Moore, 1997). In general, contractionary monetary policy results in the restricted overall supply of funds available to firms and higher external finance premium either due to changes in the overall supply of intermediate credit (bank lending sub-channel) or due to changes in the creditworthiness of firms (balance sheet sub-channel). In turn, this leads to lower investment spending, lower expectations about future net cash flows and lower stock prices. In addition, Bernanke and Kuttner (2005) provide evidence for the risk premium channel of monetary policy. In

\footnotetext{
${ }^{1}$ The global financial crisis of 2007-2009 has rekindled the academic debate of the early 2000s regarding the appropriate response of monetary policy to financial developments (Bernanke and Gertler, 1999; Cecchetti et al. 2000). Recent empirical studies suggest that monetary policy focus during the crisis may have shifted from the price stabilisation objective towards financial stability (Baxa et al., 2013).

${ }^{2}$ See Sellin (2001) for a thorough survey of the early studies investigating the link between monetary policy and stock prices.
} 
response to monetary policy tightening, the equity premium on stocks goes up either due to higher perceived riskiness of firms or increased risk aversion among investors. Consequently, current stock prices decline.

Smaller firms are typically less immune to adverse conditions stemming from tighter monetary conditions (Gertler and Gilchrist, 1994; Perez-Quiros and Timmermann, 2000; Laborda et al., 2016). As Kontonikas and Kostakis (2013) argue, this is a reasonable hypothesis since optimal risk management procedures are too costly for small companies to bear. Furthermore, small companies are less well collateralised and, subsequently, more likely to be harmed due to the "flight to quality lending" by creditors. The literature on the effects of capital market imperfections often uses firm's size as a proxy for financial constraints (Fazzari et al., 1988; Kashyap et al., 1994) arguing that smaller firms are typically younger firms, have higher agency costs of debt, and find it more difficult to raise capital due to their limited ownership base. Moreover, the access of small companies to intermediated capital is restricted, and when the overall supply of bank loans decreases, credit lines for these companies are the first to be cut. Previous studies provide empirical evidence consistent with the "size-effect" of monetary policy, whereby smaller stocks are more exposed to monetary policy shocks (Thorbecke, 1997; Ehrmann and Fratzscher, 2004; Jansen and Tsai, 2010; Kontonikas and Kostakis, 2013; Maio, 2014).

The empirical literature investigating the effect of monetary policy shifts on stock valuation, at the market or portfolio level, generally employs one of the following methodologies: an event study approach that focuses on high-frequency (daily or even intraday) reaction to news about monetary policy (Bernanke and Kuttner, 2005; Kurov, 2010; Lucca and Moench, 2015); and a vector autoregressive (VAR) model, typically estimated with monthly data (Thorbecke, 1997; Bernanke and Kuttner, 2005; Kontonikas and Kostakis, 2013). Both approaches commonly use shocks in the federal funds rate (FFR) as the proxy for monetary policy surprises and find that tightening shocks are associated with a significant decline in stock prices. The response is stronger for smaller stocks, consistent with the "sizeeffect" of monetary policy actions (Thorbecke, 1997; Ehrmann and Fratzscher, 2004; Jansen and Tsai, 2010; Kontonikas and Kostakis, 2013; Maio, 2014). Furthermore, the monetary policy effect on stock prices is found to be stronger during bad economic times and in bear markets (Basistha and Kurov, 2008; Jansen and Tsai, 2010).

Most of the existing empirical studies do not directly address the simultaneity problem, which stems from the potential response of monetary policy to stock market developments, and simply focus on the reaction of stock prices to monetary policy shocks. In 
two influential studies, however, Rigobon and Sack $(2003 ; 2004)$ show that the relationship between the US monetary policy and stock valuation is bi-directional. ${ }^{3}$ The use of ultra-high frequency data should help to alleviate the simultaneity bias (Kurov and $\mathrm{Gu}, 2016$ ), but as Bjornland and Leitemo (2009) point out, this implies that we can only analyse how asset prices are associated with particular policy actions in the very short-run. The high-frequency event studies therefore ignore the dynamic adjustments that follow the initial shock. Bjorn land and Leitemo (2009) address the interdependence between monetary policy and stock valuation using a structural VAR (SVAR) model. They allow for the simultaneous interaction between the FFR and stock market developments by imposing the long-run monetary neutrality. Their evidence, over the period 1983-2002, is consistent with the strong interdependence between interest rate setting and real stock prices at the market level (S\&P500 index), since the latter falls immediately following a tightening shock, while a positive stock price shock leads to an increase in the FFR. ${ }^{4}$

We follow Bjornland and Leitemo (2009) by employing the SVAR model for the US and extend their work in two important directions. First, we modify their model in line with the approach of Brissimis and Magginas (2006). The sample period spans 1994:2 - 2007:7 and corresponds to the period of increasing transparency in US monetary policy conduct and FFR targeting. By ending the sample prior to the onset of the recent financial crisis, we isolate the potential effects of the crisis and focus on the conventional monetary policy, as opposed to the non-conventional policy interventions that intensified following the collapse of Lehman Brothers in September 2008. Our empirical analysis for market-wide stock developments generally confirms Bjornland and Leitemo's (2009) results, albeit suggesting a weaker reaction of the FFR to stock price shocks.

Second, in addition to the aggregate stock market, we use data on ten size-sorted portfolios. This allows us to examine whether the "size-effect" of monetary policy is robust to accounting for the interdependence between the policy interest rate and stock valuation. We find that the size of a firm determines the magnitude of the stock price reaction to FFR shocks which also displays an interesting dynamic pattern. The response is stronger for larger stocks immediately following the monetary policy shock, but it subsequently declines. Meanwhile, smaller stocks exhibit the opposite behaviour. Thus, the prediction of the

\footnotetext{
${ }^{3}$ Using a combination of high- and low-frequency data, D'Amico and Farka (2011) also provide evidence supporting the strong interdependence between the US stock market and monetary policy. In particular, they find that monetary policy tightening is associated with declining stock market, while the Fed responds to a positive stock market shock by raising the policy rate.

${ }^{4}$ Similar results are also reported by Bjornland and Jacobsen (2013) for the longer sample period 1983-2010.
} 
monetary policy transmission channels regarding the stronger response of smaller stocks to policy shocks does materialise, albeit not instantaneously. Previous empirical studies that examine monetary policy effects on the performance of liquid and illiquid stocks suggest that liquidity considerations may be relevant in explaining the stronger instantaneous reaction of larger stocks. Larger stocks exhibit superior liquidity properties (Amihud, 2002) and are likely to be used by investors to rebalance their portfolios when monetary policy news arise, leading to a significant stock price reaction (Nyborg and Ostberg, 2014). On the other hand, trading in less liquid shares on the days that monetary policy news becomes available does not exhibit an overall direction that is as consistent as in the case of more liquid shares (Florackis et al., 2014). Moreover, Jensen and Moorman (2010) point out that following a shift to expansive monetary policy, improving liquidity conditions should lead to the declining illiquidity premium and illiquid stocks should outperform the liquid ones. But, crucially, this process is not instantaneous. These arguments are consistent with the delayed effect of monetary policy on smaller stocks found in this paper.

The remainder of the paper has the following structure. Section 2 describes the SVAR methodology. Data and sample period are discussed in Section 3. Section 4 contains the empirical findings. Robustness analysis is discussed in Section 5, while Section 6 concludes.

\section{SVAR methodology}

This paper employs the SVAR model for the US in line with Bjornland and Leitemo (2009) to analyse the interdependence between monetary policy and stock price changes at the market and portfolio level. The model is identified through the combination of standard short-run restrictions and one long-run restriction consistent with long-run monetary neutrality. ${ }^{5}$ Furthermore, we modify the model of Bjornland and Leitemo (2009) in line with the approach of Brissimis and Magginas (2006) that helps to resolve the price puzzle and produces the sharper measure of monetary policy shocks. ${ }^{6}$ Firstly, we include the composite leading economic indicator published by the Conference Board as the measure of future economic activity instead of commodity price inflation. As in Brissimis and Magginas (2006), this forward-looking variable is lagged by one month. The reason is that some of the data used to compose the Conference Board leading Economic index for the US is available

\footnotetext{
5 The combination of short- and long-run restrictions also addresses the criticism towards the identification schemes solely based upon long-run restrictions (Faust and Leeper, 1997).

${ }^{6}$ The price puzzle refers to a positive response of goods' prices following a contractionary monetary policy shock. According to Sims (1992), the price puzzle may be generated if some information that policy makers have about inflationary pressures is not included in the model.
} 
with a lag of at least fifteen days since the end of the month under consideration. In addition, the current-month expected level of the monetary policy rate enters the VAR system as an exogenous variable. The expected policy rate is measured by the rate on the 1-month FFR futures contract on the last business day in the previous month. Additionally, we include exogenously - the dummy variable that takes the value of one in September 2001, and zero otherwise, to account for the effects of the terrorist attacks. ${ }^{7}$

The endogenous state vector contains the following variables: the first difference in the annual change of the (log) composite leading economic indicator lagged by one month $\left(\Delta l e a d_{t-1}^{a}\right)$, the output gap $\left(\operatorname{gap}_{t}\right)$, the first difference in annual consumer price inflation $\left(\Delta \pi_{t}^{a}\right)$, monthly real stock returns $\left(\Delta s p_{t}\right)$ and the policy rate (effective FFR; $\left.i_{t}\right)^{8}$ :

$$
Z_{t}=\left[\Delta l e a d_{t-1}^{a}, \operatorname{gap}_{t}, \Delta \pi_{t}^{a}, \Delta s p_{t}, i_{t}\right]^{\prime}
$$

Ignoring any deterministic terms for notational convenience, the $p$-order $n$-variable structural autoregressive model may be written as follows (Kilian, 2011):

$$
\begin{aligned}
& B_{0} Z_{t}=B_{1} Z_{t-1}+B_{2} Z_{t-2}+\ldots+B_{p} Z_{t-p}+\varepsilon_{t} \\
& B(L) Z_{t}=\varepsilon_{t}
\end{aligned}
$$

where $Z_{t}$ is the ( $\left.n \times 1\right)$ vector containing $n$ endogenous variables, $B_{0}$ is the $(n \times n)$ matrix of contemporaneous response coefficients, $B_{i}$, for $i=1,2, \ldots, p$, is the $(n \times n)$ matrix of lag coefficients, $\varepsilon_{t}$ denotes the (n $\times 1$ ) vector of serially uncorrelated structural innovations with the zero mean and variance-covariance matrix $\Sigma_{\varepsilon}=\mathrm{E}\left(\varepsilon_{t} \varepsilon_{t}^{\prime}\right)$, and $B(L)=B_{0}-B_{1} L-B_{2} L^{2}-\ldots-$ $B_{p} L^{p}$ (Kilian, 2011).

In order to implement long-run restrictions, the structural VAR model must be expressed in its vector moving average (VMA) form. From Equation (3) it follows that:

$$
Z_{t}=B(L)^{-1} \varepsilon_{t}=C(L) \varepsilon_{t}
$$

where $C(L)=B(L)^{-1}$ denotes the $(n \times n)$ matrix of polynomial lags $C(L)=\left[C_{i j}(L)\right]$, for $i, j=$ $1, \ldots, n$. Each endogenous variable in the system is now expressed in terms of the current and

\footnotetext{
7 The results are robust to the exclusion of this dummy.

${ }^{8}$ In line with Bjornland and Leitemo (2009), the series of annual consumer price inflation as well as the annual change in the leading economic indicator are differenced to stationarity for the sample period considered.
} 
past structural shocks. An individual coefficient $c_{i j}(k)$ of a polynomial $C_{i j}(L)=\sum_{k=0}^{\infty} c_{i j}(k)$ denotes the response of a variable $i$ to a structural shock in a $j$ variable after $k$ periods.

Contemporaneous relationships among endogenous variables preclude the estimation of the structural model by the ordinary least squares method (OLS). Therefore, the reducedform of the model should be derived first, pre-multiplying both sides of Equation (3) by $B_{0}{ }^{-1}$ :

$$
A(L) Z_{t}=w_{t}
$$

where $A(L)=I-A_{1} L-A_{2} L^{2}-\ldots-A_{p} L^{p}=B_{0}{ }^{-1} B(L)$ represents the reduced-form parameters and $w_{t}=B_{0}^{-1} \varepsilon_{t}$ denotes the reduced-form residuals that are assumed to be serially uncorrelated, with the zero mean and constant variance-covariance matrix $\Sigma_{\mathrm{w}}$. Note that the matrix $\Sigma_{\mathrm{w}}$ can be written as follows:

$$
\Sigma_{w}=B_{0}^{-1} \varepsilon_{t}\left(B_{0}^{-1} \varepsilon_{t}\right)^{\prime}=B_{0}^{-1} \Sigma_{\varepsilon} B_{0}^{-1^{\prime}}
$$

Provided that the reduced-form VAR satisfies the stability condition and is invertible, the corresponding reduced-form VMA representation is as follows:

$$
Z_{t}=A(L)^{-1} w_{t}=D(L) w_{t}
$$

Considering that the reduced-form innovations are the linear combinations of structural innovations denoted by $w_{t}=B_{0}^{-1} \varepsilon_{t}$, the long-run expression of the model can be derived from Equations (4) and (7):

$$
\begin{aligned}
& C(L) \varepsilon_{t}=D(L) w_{t}=D(L) B_{0}^{-1} \varepsilon_{t} \\
& C(L)=D(L) B_{0}^{-1}
\end{aligned}
$$

For $L=1$ :

$$
C(1)=D(1) B_{0}^{-1}
$$

where the matrix $C(1)$ represents the long-run responses of the levels of endogenous variables to structural shocks, $D(1)=A(1)^{-1}$ and $A(1)=I-A_{1}-\ldots-A_{p}$. 
There are $n^{2}+n^{2} p$ free structural parameters in $B(L)$ and another $\left(n^{2}+n\right) / 2$ unique elements in the variance-covariance matrix of structural residuals. The OLS estimation of the reduced-form VAR in Equation (5) provides $n^{2} p$ parameters of the $A(1)$ matrix polynomial. By inversion of $A(1)$, it is possible to obtain $D(1)$. From the estimated variance-covariance matrix $\Sigma_{\mathrm{w}}$ further $\left.\left(n^{2}+n\right)\right) / 2$ distinct parameters are retrieved. Hence, $n^{2}$ restrictions on the system are needed to achieve the identification of the structural parameters. It is the standard practice to assume that the structural shocks are orthogonal and normalised to have unit variance. ${ }^{9}$ This is equivalent to imposing $(n(n-1)) / 2$ and $n$ restrictions, respectively. From equation (6):

$$
\Sigma_{w}=B_{0}^{-1} I_{n} B_{0}^{-1^{\prime}}=B_{0}^{-1} B_{0}^{-1^{\prime}}
$$

The structural model can then be identified if the remaining $(n(n-1)) / 2$ restrictions are placed on either the inverse of the contemporaneous matrix $B_{0}{ }^{-1}$, the matrix of long-run responses $C(1)$ or across both matrices.

In order to fully identify our structural model, twenty five restrictions must be imposed. The assumption of the unit variance of orthogonal structural shocks provides fifteen restrictions and additional ten restrictions are required to completely identify the system. The identification approach involves the combination of short-run and long-run restrictions. Short-run restrictions of no contemporaneous relationship between variables are equivalent to setting relevant elements of the matrix $B_{0}{ }^{-1}$ equal to zero. With respect to long-run restrictions, consider a non-stationary variable $i$ that enters endogenous vector of the VAR model in a differenced (stationary) form. The long-run restriction of no permanent effect of a variable $j$ on the level of a variable $i$ implies that the infinite cumulative effect of a structural shock $\varepsilon_{j}$ on $\Delta i$ must be equal to zero, i.e. $\sum_{k=0}^{\infty} c_{i j}(k)=0$ (Blanchard and Quah, 1989).

Using Equations (7) and (8), nine short-run zero restrictions are denoted by zeros in the first three rows of the matrix $B_{0}{ }^{-1}$ as follows:

\footnotetext{
${ }^{9}$ This implies that the matrix $\Sigma_{\varepsilon}$ is the identity matrix $I$. Alternatively, the diagonal elements of $\Sigma_{\varepsilon}$ may be left unconstrained and, instead, either the diagonal elements in contemporaneous matrix could be set to unity or two approaches can be combined (Kilian, 2011).
} 


$$
\overbrace{\left[\begin{array}{l}
\Delta l e a d_{t-1}^{a} \\
\text { gap }_{t} \\
\Delta \pi_{t}^{a} \\
\Delta s p_{t} \\
i_{t}
\end{array}\right]}^{Z_{t}}=D(L) \overbrace{\left[\begin{array}{ccccc}
\beta_{11} & 0 & 0 & 0 & 0 \\
\beta_{21} & \beta_{22} & 0 & 0 & 0 \\
\beta_{31} & \beta_{32} & \beta_{33} & 0 & 0 \\
\beta_{41} & \beta_{42} & \beta_{43} & \beta_{44} & \beta_{45} \\
\beta_{51} & \beta_{52} & \beta_{53} & \beta_{54} & \beta_{55}
\end{array}\right]}^{B_{0}^{-1}} \overbrace{\left[\begin{array}{l}
\varepsilon_{t}^{\text {lead }} \\
\varepsilon_{t}^{\text {gap }} \\
\varepsilon_{t}^{\pi} \\
\varepsilon_{t}^{s p} \\
\varepsilon_{t}^{m p}
\end{array}\right]}^{\varepsilon_{t}}
$$

In the spirit of Christiano, Eichenbaum and Evans (2005), it is assumed that monetary policy has no contemporaneous impact on macroeconomic variables; however, monetary policy can respond to shocks in these variables within the same period. Consequently, the leading economic indicator, output gap, and inflation are ordered above the interest rate in the state vector $Z_{t}$. Furthermore, we assume a recursive scheme within the macroeconomic block. The lagged growth rate in the composite leading indicator is ordered first as it is assumed that it's not contemporaneously affected by any other variable in the system. Consumer price inflation can respond to both the output gap and leading economic indicator contemporaneously. With respect to financial variables, all variables in the system are allowed to have an immediate impact on the real stock returns and monetary policy rate. However, as in the case of monetary policy, the stock returns may affect the macroeconomic variables only with a lag. Most importantly, the two final rows of $B_{0}{ }^{-1}$ imply that the short-run contemporaneous relationship between real stock prices remains unrestricted, i.e. neither $\beta_{45}$ nor $\beta_{54}$ is set to zero.

The final (tenth) restriction is applied with respect to the long-run relationship between the monetary policy instrument and real stock prices. It implies that monetary policy shock has no long-run effect on the real stock prices (Bjornland and Leitemo, 2009). This restriction is reflected in the long-run response matrix $C(1)$ by setting the infinite sum of the relevant lag coefficients in Equation (10), $C_{45}(1)=\sum_{k=0}^{\infty} C_{45}(k)$, equal to zero. Given that $C_{45}(1)=0$, it follows that: ${ }^{10}$

$$
D_{41}(1) \beta_{15}+D_{42}(1) \beta_{25}+D_{43}(1) \beta_{35}+D_{44}(1) \beta_{45}+D_{45}(1) \beta_{55}=0
$$

\footnotetext{
${ }^{10}$ After taking into account the short-run restrictions, Equation (13) shrinks to $D_{44}(1) \beta_{45}+D_{45}(1) \beta_{55}=0$.
} 


\section{Data and sample}

The empirical analysis is conducted using monthly US data over the period 1994:2 2007:7. ${ }^{11}$ Monetary policy conduct during the sample period is characterised by the FFR targeting, i.e. setting the target level for the interest rate on overnight loans of reserves between banks (Bernanke and Mihov, 1998; Romer and Romer, 2004). The start of the sample corresponds to the point in time when the Fed initiated the practice of announcing changes in the target level of the FFR and reduced substantially the number of inter-meeting policy rate changes. This has led to the greater transparency and predictability of monetary policy conduct (Fawley and Neely, 2014). The sample ends in July 2007, prior to the onset of the recent financial crisis.

The start of the financial crisis is typically dated to August 2007 when doubts about financial stability emerged and the first central bank interventions in response to increasing interbank market pressures took place (Brunnermeier, 2009). The financial market turmoil at the height of the crisis in late 2008 and the Fed's policy measures implemented at that time may have led to substantial changes in the relationship between stock prices and the federal funds rate. Hence, our choice of the sample allows isolating these potentially distortive effects of the crisis. Nevertheless, in the robustness section we test the sensitivity of the analysis to the extension of the sample until December 2008 when the zero lower bound was reached. The main findings remain largely unchanged. Given that the normalisation of the Fed's monetary policy is currently under its way, this paper is focused on the conventional monetary policy. The effects of the non-conventional policies, including forward guidance at the zero lower bound, the provision of liquidity facilities and quantitative easing implemented since late 2008, are not examined. Consequently, the estimation sample does not go beyond December 2008.

The macroeconomic series include the output gap, annual inflation and annual changes in the leading economic indicator. The output gap $\left(g_{a p}\right)$ is measured using the deviations of the actual log industrial production (IP) from its potential level. The latter is obtained by applying the Hodrick-Prescott filter to the actual industrial production series. ${ }^{12}$ Annual consumer price inflation $\left(\pi_{t}^{a}\right)$ is calculated as the annual change in the log Consumer

\footnotetext{
11 The sample period (as reported) excludes the months reserved for the lags of endogenous variables.

12 Our main results are largely unchanged when we use quadratic detrending to measure the output gap. The correlation between the two measures of output gap is 0.44 and 0.52 over the sample periods 1994:2 - 2007:7 and 1994:2 - 2008:12, respectively. As shown in Figure B1 in Appendix B, the output gap based on quadratic detrending exhibits larger extreme values that may be implausible, thus, the HP filter is our preferred approach. See Weidner and Williams (2009) for a discussion of the size of output gap in the US.
} 
Price Index (CPI) for all items. The Conference Board Leading Economic Index (CBLEI) is a proxy for future expectations about economic activity in the US. The annual growth in the leading economic indicator $\left(\operatorname{lead}_{t}^{a}\right)$ is calculated as the change in the log CBLEI from a year ago. Seasonally adjusted data on the IP and CPI, and monthly averages of the effective FFR are collected from the FRED database maintained by the Federal Reserve Bank of St. Louis. Data for the CBLEI is obtained from Datastream. ${ }^{13}$

With respect to stock price data, monthly real stock market returns $\left(\Delta s p_{t}\right)$ are calculated as the monthly change in the log of the S\&P500 stock market index deflated by the $\log$ CPI. Monthly averages of the S\&P500 index are calculated using daily figures from Datastream. In addition to market returns, we use real returns on the value-weighted sizesorted stock portfolios (excluding dividends). Data on the decile portfolios formed according to firm's size (market value) are collected from the database of K. French. ${ }^{14}$ Finally, monthly averages of the effective FFR are collected from the FRED database, while data on the FFR futures contract rate is obtained from Bloomberg. ${ }^{15}$

\section{[TABLE 1 HERE]}

Summary statistics for monthly real stock returns at the market and portfolio level are reported in Table 1. The average real return on the market is about $0.51 \%$ per month. The average return tends to decline, albeit not monotonically, as we move from small to large stocks. The smallest stocks (decile 1) earn the highest average return $(0.87 \%$ p.m.), while the largest stock (decile 10$)$ the lowest ( $0.44 \%$ p.m.). Moreover, smaller stocks are more volatile as compared to the larger ones.

\section{4. $\quad$ Results}

\subsection{Stock market}

The estimated model uses four lags of the endogenous variables and satisfies the stability condition (all inverse roots lie inside the unit circle) and diagnostic tests with respect to the heteroskedasticity and serial correlation in the residuals. As recommended by Sims and Zha (1999), we report the impulse response functions (solid line) together with 68\%

\footnotetext{
${ }^{13}$ Figure B2 in Appendix B plots these time series over the sample period 1994:2 - 2008:12.

14 The data library is accessible via this link: http://mba.tuck.dartmouth.edu/pages/faculty/ken.french/data_library.html\#Research.

15 The plots of monthly returns on the size-sorted portfolios are provided in Figure B3 of Appendix B.
} 
probability bands (dashed lines). ${ }^{16}$ The median value is chosen as the central measure of impulse responses. The Monte Carlo integration with 10,000 draws is used to obtain the Bayesian simulated distribution of impulse response functions using the approach for justidentified VAR systems. ${ }^{17}$

The impulse response functions of the FFR, real stock prices, annual inflation and output gap in response to a contractionary monetary policy shock are reported in Figure 1. The FFR increases and peaks on the impact, with the effect dying out quickly. Monetary policy tightening has a negative effect on both inflation and output gap. The output gap returns to its initial level after approximately one year following the shock. There is no evidence of the price puzzle. The impact of monetary policy shocks on inflation is more persistent, as compared to its impact on the output gap, with inflation remaining 0.6 percentage points below its base 3 years after the shock. With regards to previous evidence, the findings of Brissimis and Magginas (2006), who use a similar VAR specification (2006) to ours, also suggest a persistent effect of monetary policy shocks on inflation. ${ }^{18}$ The response of inflation implies a significantly higher real interest rate. ${ }^{19}$ Nevertheless, as shown in the robustness analysis, the inflation response is more in line with long-run monetary policy neutrality when the sample is extended to incorporate the financial crisis. The decline in the inflation rate remains quite persistent; however, the policy effect becomes insignificant over the longer horizon.

\section{[FIGURE 1 HERE]}

\footnotetext{
16 According to Sims and Zha (1999), the traditional symmetric confidence intervals, reported as one or two standard errors around the point estimate of an impulse response function, may be misleading. Such error bands confound information regarding the location of the coefficient values with the information about the overall model fit. They show that the Bayesian posterior probability bands, simulated using Monte Carlo integration, may be more useful than the confidence intervals based upon the estimates of standard errors. The fractiles correspond to one standard deviation if the standard error bands were used.

17 The draws are made from the posterior distribution for VAR parameters and residuals under the standard uninformative ("flat") prior for a multivariate regression model (Doan, 2015). It is important to note that the structural model depends on the new set of parameters for each Monte Carlo draw and model's parameters must be reset accordingly prior to the generation of new impulse response functions. This is unlike Bjornland and Leitemo (2009) where the original OLS estimates of VAR coefficients are used in in each draw (Doan, 2015).

${ }^{18}$ Specifically, in Figure 2 of their paper, Brissimis and Magginas (2006) show that following a contractionary monetary policy shock, consumer prices decline continuously, and significantly so, over a horizon of 48 months. At the same time, the policy rate returns to the initial level very quickly and its impact on industrial production becomes insignificant after one year.

19 This finding appears to be at odds with monetary policy neutrality. We should point out, though, that in our framework, the neutrality restriction refers to the absence of a long-run effect from monetary policy on the price of stocks. Moreover, the notion of monetary policy non-neutrality is challenged by the findings of some recent studies. Hanson and Stein (2016, p.430) admit that "none of our evidence directly refutes the long-run nonneutrality hypothesis that policy is somehow able to move expected real rates far out into future". Nakamura and Steinsson (2017) examine the impact of monetary policy shocks, identified using a high-frequency data approach, on real interest rates, expected inflation, and expected output growth. Their evidence suggests that real interest rates increase several years out in the future in response to a monetary policy tightening shock. We thank an anonymous referee for raising this point.
} 
The results in Figure 1 also indicate that monetary policy tightening has a negative and statistically significant effect on real stock prices. An unexpected $1 \%$ increase in the FFR is associated with an immediate real stock price decline of about $8 \%$. The stock price response is statistically significant for two months after the shock and thereafter becomes insignificant. The finding of the significant stock market response to monetary policy shocks is consistent with the existing empirical evidence (Thorbecke, 1997; Bernanke and Kuttner, 2005; Bjornland and Leitemo, 2009). It can be rationalised by considering that monetary policy tightening may be associated with an increase in the rate used to discount future dividends and/or a decline in expected future corporate profitability, due to lower spending and output. The stock market response to monetary policy shocks is short-lived, consistent with the long-run monetary neutrality assumption. As Bjornland and Leitemo (2009) argue, this pattern may be related to the fact that as the FFR falls, following the initial tighteningrelated peak, the discounted value of dividends increases while output and profits also expand, leading to the stock price "normalisation".

\section{[FIGURE 2 HERE]}

Figure 2 shows the dynamic effects of a $1 \%$ positive shock to real stock prices. Both the inflation rate and output respond positively to higher stock market valuation, albeit the response becomes significant with a delay and the magnitude of the impact is relatively small. The positive effect of higher stock prices on the inflation and output may be reflecting the wealth and balance sheet effects with respect to consumption and investment that boost aggregate demand (Chen et al., 2012). With respect to the policy reaction to stock market developments, the Fed tightens monetary policy in response to the positive real stock price shock by increasing the FFR. The response, however, becomes statistically significant only after several months following the shock. The sign of the response is consistent with previous studies (Rigobon and Sack, 2003; Bjornland and Leitemo, 2009; D'Amico and Farka, 2011; Bjornland and Jacobsen, 2013). Thus, despite the relatively small magnitude of the stock price effect, our results overall reveal the interdependence between the monetary policy rate and stock market developments.

\subsection{Size-sorted portfolios}

In this section, the SVAR model is estimated for each size decile portfolio by replacing the real stock market returns in the state vector with the relevant portfolio returns. We focus our attention on the response of stock prices to monetary policy shocks, rather than 
the other way around..$^{20}$ The aim is to investigate whether the "size effect" of monetary policy shocks is present in the sample period considered. The impulse responses of inflation and output gap to monetary policy shocks are similar to those obtained in the previous section and are not shown to preserve space.

\section{[FIGURE 3 HERE]}

As we can see in Figure 3, a positive FFR shock leads to a decline in real stock prices across the ten size-sorted portfolios. The immediate stock price response to the monetary policy shock is statistically significant across all deciles except for the smallest stocks (decile 1). Two interesting findings that deserve a more detailed discussion can be noted in Figure 3. Contrary to the credit channel prediction, the immediate effect of the contractionary monetary policy shock is stronger for larger firms, with the price of the largest stocks (decile 10) declining by about $13 \%$ in response to an unexpected $1 \%$ increase in the FFR. Meanwhile, the smallest firms do not see their stocks being significantly affected in the first month. Starting with the second decile portfolio, the stock price decline gradually becomes more pronounced as well as statistically significant. ${ }^{21}$ However, this pattern disappears when we examine the second-period impulse responses.

This is seen clearly in Table 2 that tabulates the initial- and second-period impulse responses. Our results indicate that the decline in the stock prices of smaller firms, following monetary policy tightening, is more persistent as compared to the response of larger firms, which is short-lived. In the second month, the smallest firms experience the largest stock price decline, down by $10 \%$, while the initial drop in the price of the largest stocks is almost fully reversed. The monetary policy effect on smaller firms remains statistically significant for several periods, while for larger firms it is not statistically significant beyond the initial period. Hence, smaller firms have greater exposure to the monetary policy-related risk as their stocks are more sensitive to changes in the policy interest rate as compared to larger firms. This finding is in line with the credit channel theory stating that more financially vulnerable and bank-dependent firms - small firms are likely to fall in this category - suffer relatively more following policy tightening. Finally, there is no significant policy impact on any of stock portfolios beyond three months after the shock with real stock prices typically returning to their initial levels within one year.

\section{[TABLE 2 HERE]}

\footnotetext{
${ }^{20}$ Results related to the reaction of monetary policy and macroeconomic variables to price developments in different size deciles are available upon request.

${ }^{21}$ The tendency for the magnitude of the policy impact to increase as we move from smaller to larger stocks is non-monotonic.
} 
To sum up, contractionary monetary policy shocks have a negative and significant short-run impact on the performance of stock portfolios sorted by firm's size. The initialperiod impulse responses indicate that larger firms are more sensitive to interest rate shocks than smaller firms, but the latter respond more strongly in the second period. Hence, we show that the "size effect" of monetary policy, whereby smaller stocks are more strongly affected by policy shifts (Thorbecke, 1997; Ehrmann and Fratzscher, 2004; Maio, 2014), materialises with a lag.

Several arguments can be made to explain the difference in the reaction to monetary policy shocks across size-sorted portfolios. The higher sensitivity of larger stocks in the initial period following the monetary policy shock may be related to their liquidity characteristics. Larger stocks are more liquid, compared to the smaller ones (Amihud, 2002). Thus, monetary policy news may be quickly incorporated in the prices of the most liquid stocks as they can be instantly traded. ${ }^{22}$ As Nyborg and Ostberg (2014) find, banks are more likely to use larger/more liquid stocks to pull back liquidity when funding conditions tighten. Provided that monetary policy affects the interbank market for liquidity, a contractionary monetary policy shock may trigger an asset sell-off by banks and levered investors with the strongest effect felt on the most liquid stocks. Florackis et al. (2014) argue that trading in less liquid shares on the days that news about monetary policy arise does not exhibit an overall direction that is as consistent as in the case of more liquid shares. The delayed reaction of smaller stocks to FFR shocks is also consistent with the results of Jensen and Moorman (2010), whereby the initial reaction to monetary policy shifts is stronger for illiquid stocks but reversing after a few months. The learning process of investors with information capacity (or attention) constraints suggests that larger stocks are likely to receive more attention and to adjust faster to fundamental shocks (Peng, 2005). The investor base matters. In contrast to large stocks, that are mainly held by institutional investors, small stocks are typically held by individuals who tend to be less sophisticated investors (Nagel, 2005; Lemmon and Portniaguina, 2006). In Zhao's (2012) model there are more informed traders of large firms, as opposed to small firms, in equilibrium. Consequently, the prices of larger stocks tend to reflect information more efficiently.

\footnotetext{
22 This argument is consistent with the greater trading activity found for larger stocks (Chordia, Huh and Subrahmanyam, 2007).
} 


\section{Robustness checks}

\subsection{Alternative lag length}

We start by considering an alternative lag length for the SVAR model. Specifically, we use six lags instead of four in the baseline estimations. ${ }^{23}$ The results for the market and portfolio returns with the SVAR(6) are shown in Figures A1 and A2, respectively. The findings are similar to those of the baseline analysis. Monetary policy tightening has a negative and significant impact on real stock prices at both the market and portfolio level. Moreover, the initial reaction of large stocks is stronger compared to that of smaller stocks, but the latter respond more strongly in the second period.

\subsection{Alternative sample period}

The sample period is extended to include the global financial crisis up until December 2008 when the short-term interest rate reached zero lower bound. ${ }^{24}$ The market-based results and size decile-based results are presented in Figures A3 and A4, respectively. They are consistent with the baseline findings, albeit with larger standard errors especially in the case of the smallest stocks' response. Overall, incorporating the financial crisis into our analysis sample does not invalidate the main conclusions regarding the impact of monetary policy shocks on the stock market and size-sorted portfolios.

\subsection{Quintile size portfolios}

Finally, Figure A5 shows the impulse response functions for the quintile size-sorted portfolios returns. An unexpected monetary policy tightening depresses real stock prices with the initial impact being stronger for larger firms. In line with the main results, the smallest stocks are more sensitive to the shock as compared to largest stocks in the second period.

\section{Conclusions}

This study examines the relationship between monetary policy and real stock prices in the US using the empirical SVAR-based framework that allows for the short-run simultaneity assuming long-run monetary neutrality. The econometric model is specified in the spirit of Bjornland and Leitemo (2009) and the identification of monetary policy shocks is further

\footnotetext{
${ }^{23}$ We also used two lags and obtain consistent results. These findings are available upon request.

${ }^{24}$ Two additional dummies are included as exogenous variables. The first (second) is equal to one in September (October) 2008 and zero otherwise. They capture the effects of the collapse of Lehman Brothers.
} 
improved as per the recommendations by Brissimis and Magginas (2006). The sample period that we analyse (1994:2-2007:7) corresponds to the period of increasing transparency in the conduct of monetary policy and allows us to focus on conventional policy shifts, captured by shocks in the federal funds rate. We confirm the results of previous studies by showing that stock prices react significantly to monetary policy changes, with expansive surprises increasing real stock prices. At the same time, monetary policy appears to react, albeit relatively weakly, to developments in the stock market. We find that the reaction of stocks to monetary policy shifts is conditional upon the size of a firm and it follows an interesting dynamic pattern. Specifically, it is stronger for larger stocks immediately following the monetary policy shock and subsequently declines, while smaller stocks exhibit the opposite behaviour. Liquidity considerations may be relevant in explaining this delayed "size effect" of monetary policy actions. 


\section{References}

Amihud, Y., 2002. Illiquidity and stock returns: Cross section and time-series effects. Journal of Financial Markets, 5, p.31-56.

Basistha, A., and Kurov, A., 2008. Macroeconomic cycles and the stock market's reaction to monetary policy. Journal of Banking and Finance, 32, p.2606-2616.

Baxa, J., Horvath, R., and Vasicek, B., 2013. Time-varying monetary-policy rules and financial stress: Does financial instability matter for monetary policy? Journal of Financial Stability, 9, p.117-138.

Bernanke, B.S., and Gertler, M., 1995. Inside the black box: The credit channel of monetary policy transmission. Journal of Economic Perspectives, 9, p.27-48.

Bernanke, B.S., and Gertler, M., 1999. Monetary policy and asset price volatility. Federal Reserve Bank of Kansas Economic Review, 84, p.18-51.

Bernanke, B.S., and Kuttner, K.N., 2005. What explains the stock market's reaction to Federal Reserve policy?. Journal of Finance, 60, p.1221-1257.

Bernanke, B.S., and Mihov, I., 1998. Measuring monetary policy. Quarterly Journal of Economics, 113, p.869-902.

Bjornland, H.C., and Jacobsen, D.H., 2013. House prices and stock prices: different roles in the US monetary transmission mechanism. Scandinavian Journal of Economics, 115, p.10841106.

Bjornland, H.C., and Leitemo, K., 2009. Identifying the interdependence between US monetary policy and the stock market. Journal of Monetary Economics, 56, p.275-282.

Blanchard, O.J., and Quah, D., 1989. The dynamic effects of aggregate demand and supply disturbances. American Economic Review, 79, p.655-673.

Brissimis, S.N., and Magginas, N.S., 2006. Forward-looking information in VAR models and the price puzzle. Journal of Monetary Economics, 53, p.1225-1234.

Brunnermeier, M.K., 2009. Deciphering the liquidity and credit crunch 2007-2008. Journal of Economic Perspectives, 23, p.77-100.

Cecchetti, S.G., Genberg, H., Lipsky, J., and Wadhwani, S., 2000. Asset prices and central bank policy. International Centre for Monetary and Banking Studies, Geneva Report on the World Economy 2.

Chordia, T., Huh, S., and Subrahmanyam, A., 2007. The cross-section of expected trading activity. The Review of Financial Studies, 20, p.709-740.

Christiano, L.J., Eichenbaum, M., and Evans, C., 2005. Nominal rigidities and the dynamic effects of a shock to monetary policy. Journal of Political Economy, 113, p.1-45. 
Cooper, R.V.L., 1974. Efficient capital markets and the quantity theory of money. Journal of Finance, 29, p.887-908.

D'Amico, S., and Farka, M., 2011. The Fed and the stock market: An identification based on intraday futures data. Journal of Business and Economic Statistics, 29, p.126-137.

Doan, T.A., 2015. RATS handbook for vector autoregressions, $2^{\text {nd }}$ edition, Estima, Evanston, IL.

Ehrmann, M., and Fratzscher, M., 2004. Taking stock: Monetary policy transmission to equity markets. Journal of Money, Credit and Banking, 36, p.719-737.

Faust, J., and Leeper, E.M., 1997. When do long-run identifying restrictions give reliable results?. Journal of Business and Economic statistics, 15, p.345-353.

Fawley, B.W., and Neely, C.J., 2014. The evolution of Federal Reserve policy and the impact of monetary policy surprises on asset prices. Federal Reserve Bank of St. Louis Review, 96, p.73-109.

Fazzari, S.R., Hubbard, G., and Petersen, B., 1988. Financing constraints and corporate Investment. Brooking Papers in Economic Activity, 1, p.141-195.

Florackis, C., Kontonikas, A., and Kostakis, A., 2014. Stock market liquidity and macroliquidity shocks: Evidence from the 2007-2009 financial crisis. Journal of International Money and Finance, 44, p.97-117.

Gertler, M. and Gilchrist, S., 1994. Monetary policy, business cycles, and the behaviour of small manufacturing firms. Quarterly Journal of Economics, 109, p.309-340.

Hanson, S.G, and Stein, J.C., 2015. Monetary policy and long-term real rates. Journal of Financial Economics, 115, p.429-448.

Jansen, D.W., and Tsai, C., 2010. Monetary policy and stock returns: Financing constraints and asymmetries in bull and bear markets. Journal of Empirical Finance, 17, p.981-990.

Jensen, G.R., and Moorman, T., 2010. Inter-temporal variation in the illiquidity premium. Journal of Financial Economics, 98, p.338-358.

Kashyap, A.K., Lamont, O.A., and Stein, J.C., 1994. Credit conditions and the cyclical behavior of inventories. Quarterly Journal of Economics, 109, p.565-592.

Kashyap, A.K., Stein, J.C., and Wilcox, D.W., 1993. Monetary policy and credit conditions: Evidence from the composition of external finance. The American Economic Review, 83, p.78-98.

Kilian, L., 2011. Structural vector autoregressions. CEPR Discussion Paper Series, Discussion paper 8515. 
Kiyotaki, N., and Moore, J., 1997. Credit cycles. Journal of Political Economy, 105, p.211248.

Kontonikas, A., and Kostakis, A., 2013. On monetary policy and stock market anomalies. Journal of Business Finance and Accounting, 40, p.1009-1042.

Kontonikas, A., MacDonald, R., and Saggu, A., 2013. Stock market reaction to Fed funds rate surprises: State dependence and the financial crisis. Journal of Banking and Finance, 37 , p.4025-4037.

Kurov, A., 2010. Investor sentiment and the stock market's reaction to monetary policy. Journal of Banking and Finance, 34, p.139-149.

Kurov, A., and Gu, C., 2016. Monetary policy and stock prices: Does the "Fed Put" work when it is most needed? Journal of Futures Markets, 36, p.1210-1230.

Laborda, J., Laborda, R., and Olmo, J., 2016. Investing in the size factor. Quantitative Finance, 16, p.85-100.

Lemmon, M., and Portniaguina, E., 2006. Consumer confidence and asset prices: Some empirical evidence. Review of Financial Studies, 19, p.1499-1529.

Lucca, D.O., and Moench, E., 2015. The pre-FOMC announcement drift. Journal of Finance, 70, p.329-371

Maio, P., 2014. Another look at the stock return response to monetary policy actions. Review of Finance, 18, p.321-371.

Mishkin, F.S., 2001. The transmission mechanism and the role of asset prices in monetary policy. NBER Working Paper Series, Working paper 8617.

Nagel, S., 2005. Short sales, institutional investors and the cross-section of stock returns. Journal of Financial Economics, 78, p.277-309

Nakamura, E., and Steinsson, J., 2017. High frequency identification of monetary nonneutrality: The information effect. Quarterly Journal of Economics, forthcoming.

Nyborg, K.G., and Ostberg, P., 2014. Money and liquidity in financial markets. Journal of Financial Economics, 112, p.30-52.

Peng, L., 2005. Learning with information capacity constraints. The Journal of Financial and Quantitative Analysis, 40, p.307-329.

Perez-Quiros, G., and Timmermann, A., 2000. Firm size and cyclical variations in stock returns. Journal of Finance, 55, p.1229-1262.

Rigobon, R., and Sack, B., 2003. Measuring the reaction of monetary policy to the stock market. Quarterly Journal of Economics, 118, p.639-669. 
Rigobon, R., and Sack, B., 2004. The impact of monetary policy on asset prices. Journal of Monetary Economics, 51, p.1553-1575.

Romer, C.D., and Romer, D.H., 2004. A new measure of monetary shocks: Derivation and implications. American Economic Review, 94, p.1055-1084.

Sellin, P., 2001. Monetary policy and the stock market: Theory and empirical evidence. Journal of Economic Surveys, 15, p.491-541.

Sims, C.A., 1992. Interpreting the macroeconomic time series facts. The effects of monetary policy. European Economic Review, 36, p.975-1000.

Sims, C.A., and Zha, T., 1999. Error bands for impulse responses. Econometrica, 67, p.11131155 .

Smirlock, M., and Yawitz, J., 1985. Asset returns, discount rate changes, and market efficiency. Journal of Finance, 40, p.1141-1158.

Thorbecke, W., 1997. On stock market returns and monetary policy. Journal of Finance, 52, p.635-654.

Weidner, J., and Williams, J.C., 2009. How big is the output gap? Federal Reserve Bank of San Francisco, Economic Letter 2009-19.

Zhao, T., 2012. Firm size, information acquisition and price efficiency. Quantitative Finance, 10, p.1599-1614. 


\section{Figure 1: Impulse responses to FFR shock}
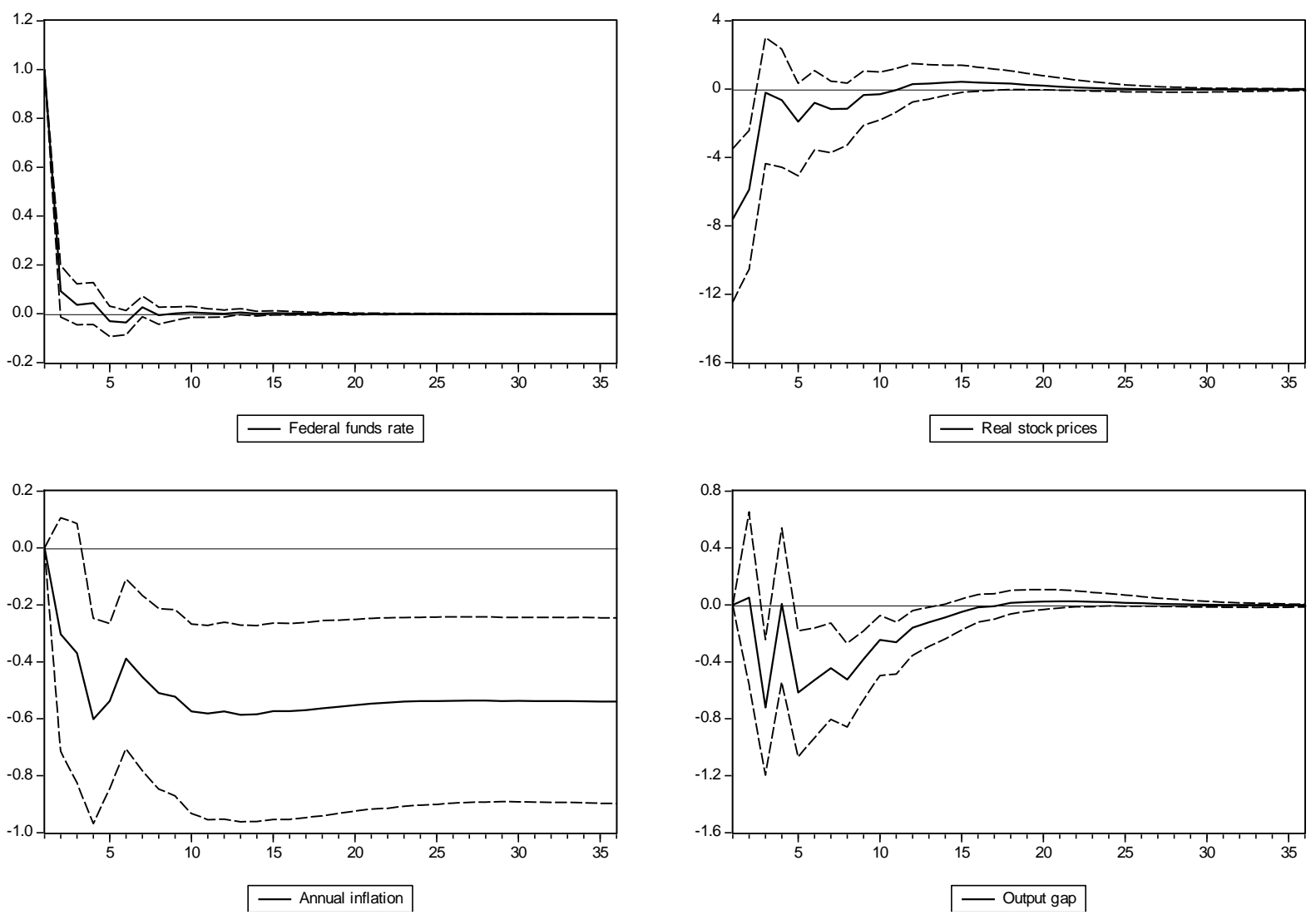

Notes: This figure plots the impulse response (solid line) of the federal funds rate, output gap, annual inflation, and real stock prices at the market level (S\&P500) following a 1-percentage-point contractionary monetary policy shock. The SVAR model is estimated over the sample period 1994:2 - 2007:7 including 4 lags. The state vector contains the first difference (lagged) in annual change of leading economic indicator $\left(\Delta l e a d^{a}{ }_{t-1}\right)$, the output gap $\left(\operatorname{gap}_{t}\right)$, the first difference in annual inflation $\left(\Delta \pi_{t}^{a}\right)$, monthly real stock market returns $\left(\Delta s p_{t}\right)$ and the effective federal funds rate $\left(i_{t}\right)$. A dummy variable that takes value of one in 2001:9 and zero otherwise and the 1-month federal funds futures contract rate (as of last business day of previous month) are included as exogenous variables. The dashed lines represent $68 \%$ Bayesian probability bands generated using Monte Carlo integration with 10000 draws as suggested by Doan (2015). 
Figure 2: Impulse responses to real stock price shock
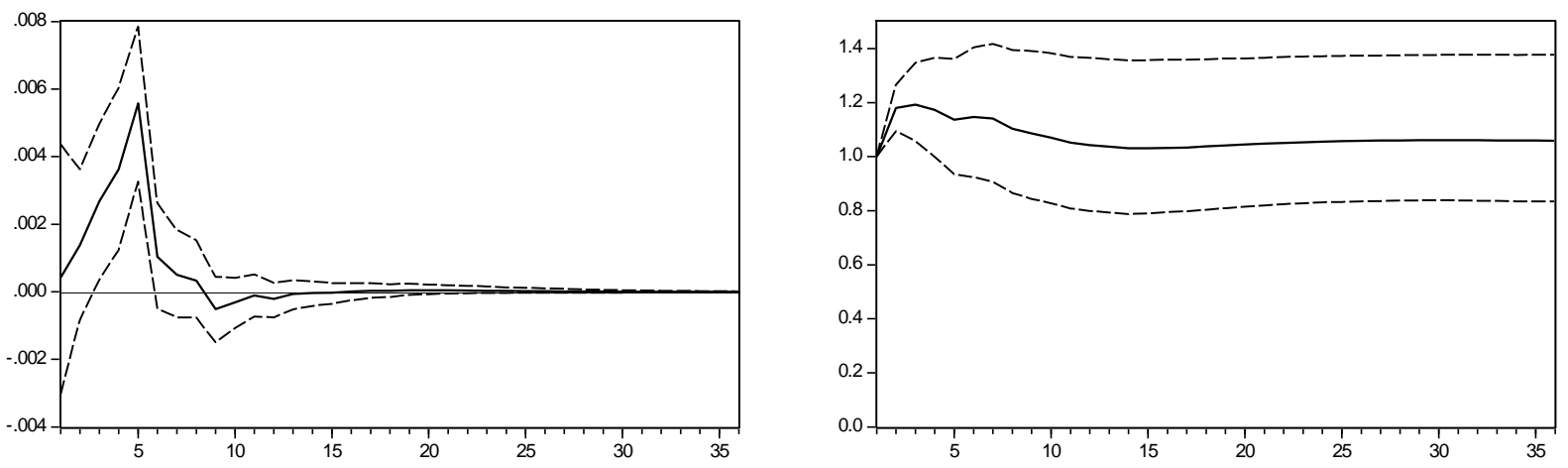

- Federal funds rate
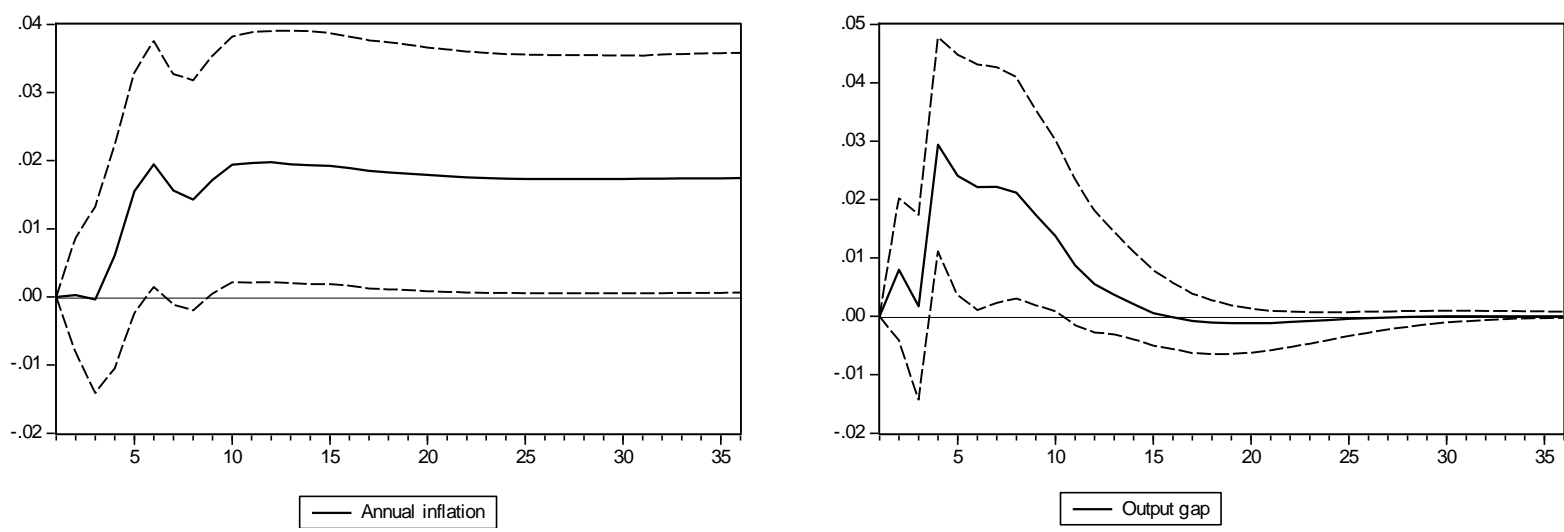

Notes: This figure plots the impulse responses (solid line) of the federal funds rate, output gap, annual inflation, and real stock prices at the market level (S\&P500) following a positive $1 \%$ real stock price shock. See also Figure 1 notes. 
Figure 3: Impulse responses to FFR shock: size-sorted portfolios
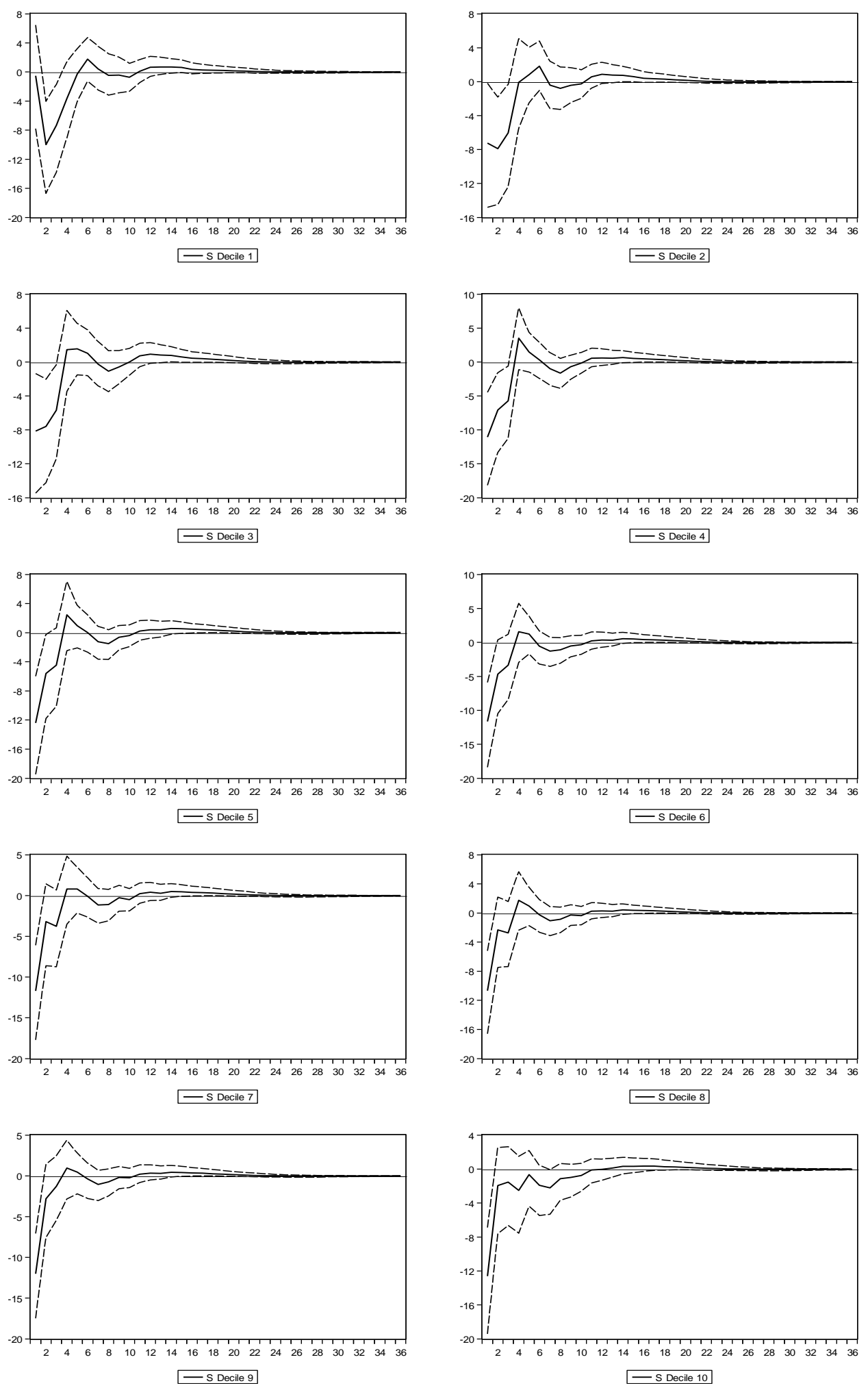

Notes: This figure plots the impulse response (solid line) of real stock prices at the portfolio level (10 size-sorted portfolios) following a 1-percentage-point contractionary monetary policy shock. The SVAR model is estimated for each size decile portfolio over the sample period 1994:2 - 2007:7 including 4 lags. The state vector contains the first difference (lagged) in annual change of leading economic indicator $\left(\Delta l e a d_{t-1}^{a}\right)$, the output gap $\left(\operatorname{gap}_{t}\right)$, the first difference in annual inflation $\left(\Delta \pi_{t}^{a}\right)$, monthly real stock portfolio returns $\left(\Delta s p_{t}\right)$ and the effective federal funds rate $\left(i_{t}\right)$. See also Figure 1 notes. 
Table 1: Summary statistics for real stock market and size-sorted portfolio returns

\begin{tabular}{|cccccc|}
\hline Returns & Mean & Median & Max & Min & Std. Dev. \\
\hline \multicolumn{5}{c|}{ Panel A: Market returns } \\
\hline Market & 0.5051 & 0.5769 & 10.3500 & -11.5131 & 3.3121 \\
\hline \multicolumn{5}{c}{ Panel B: Size-sorted portfolio returns } \\
\hline Decile 1 & 0.8716 & 1.2389 & 25.4848 & -23.5809 & 6.0805 \\
\hline Decile 2 & 0.7781 & 0.8644 & 22.5794 & -26.0384 & 6.3909 \\
\hline Decile 3 & 0.6742 & 1.2575 & 16.5870 & -23.8594 & 5.8442 \\
\hline Decile 4 & 0.5297 & 1.2584 & 15.2194 & -21.9008 & 5.5935 \\
\hline Decile5 & 0.6105 & 1.2885 & 13.4505 & -22.8125 & 5.4484 \\
\hline Decile 6 & 0.5344 & 1.1608 & 9.2761 & -22.4868 & 4.9117 \\
\hline Decile 7 & 0.7682 & 1.1055 & 12.0566 & -20.9726 & 4.7182 \\
\hline Decile 8 & 0.5982 & 0.9888 & 11.8445 & -19.0088 & 4.8112 \\
\hline Decile 9 & 0.6661 & 1.3482 & 8.6728 & -16.3273 & 4.1423 \\
\hline Decile 10 & 0.4442 & 0.8267 & 9.4523 & -15.8581 & 4.2214 \\
\hline
\end{tabular}

Notes: This table reports the summary statistics for monthly real returns on the stock market (Panel A) and the 10 size-sorted portfolios (Panel B) over the sample period 1994:02 - 2007:7.

Table 2: Initial and second period responses to FFR shock: size-sorted portfolios

\begin{tabular}{|lcc|}
\hline & Initial period & Second period \\
\hline Decile 1 & -0.514 & $-9.973^{*}$ \\
& $(-7.800 ; 6.470)$ & $(-16.712 ;-4.034)$ \\
\hline Decile 2 & $-7.250^{*}$ & $-7.907^{*}$ \\
& $(-14.800 ;-0.182)$ & $(-14.489 ;-1.817)$ \\
\hline Decile 3 & $-8.156^{*}$ & $-7.604^{*}$ \\
& $(-15.448 ;-1.350)$ & $(-14.223 ;-2.028)$ \\
\hline Decile 4 & $-11.068^{*}$ & $-7.073^{*}$ \\
& $(-18.149 ;-4.471)$ & $(-13.325 ;-1.581)$ \\
\hline Decile 5 & $-12.392^{*}$ & $-5.605^{*}$ \\
& $(-19.449 ;-5.992)$ & $(-11.783 ;-0.238)$ \\
\hline Decile 6 & $-11.652^{*}$ & -4.672 \\
& $(-18.369 ;-5.881)$ & $(-10.482 ; 0.389)$ \\
\hline Decile 7 & $-11.694^{*}$ & -3.189 \\
& $(-17.709 ;-6.097)$ & $(-8.622 ; 1.440)$ \\
\hline Decile 8 & $-10.670^{*}$ & -2.335 \\
& $(-16.586 ;-5.198)$ & $(-7.484 ; 2.193)$ \\
\hline Decile 9 & $-12.006^{*}$ & -2.798 \\
& $(-17.473 ;-7.067)$ & $(-7.575 ; 1.397)$ \\
\hline Decile 10 & $-12.601^{*}$ & -1.937 \\
& $(-19.419 ;-6.879)$ & $(-7.632 ; 2.512)$ \\
\hline
\end{tabular}

Notes: This table reports the initial and second-period impulse responses of real stock prices at the portfolio level (10 size-sorted portfolios) following a 1-percentage-point contractionary monetary policy shock. The SVAR model is estimated for each size decile portfolio over the sample period 1994:2 - 2007:7 including 4 lags. The state vector contains the first difference (lagged) in annual change of leading economic indicator $\left(\Delta l e a d^{a}{ }_{t-1}\right)$, output gap $\left(\operatorname{gap}_{t}\right)$, the first difference in annual inflation $\left(\Delta \pi_{t}^{a}\right)$, monthly real stock portfolio returns $\left(\Delta s p_{t}\right)$ and the effective federal funds rate $\left(i_{t}\right)$. A dummy variable that takes value of one in 2001:9 and zero otherwise and the 1-month federal funds futures contract rate (as of last business day of previous month) are included as exogenous variables. The $68 \%$ Bayesian probability bands generated using Monte Carlo integration with 10000 draws as suggested by Doan (2015) are presented in parentheses. * denote statistically significant impulse responses, i.e. probability bands do not include zero. 


\section{Appendix A}

\section{Figure A1: Impulse responses to FFR shock - VAR(6)}
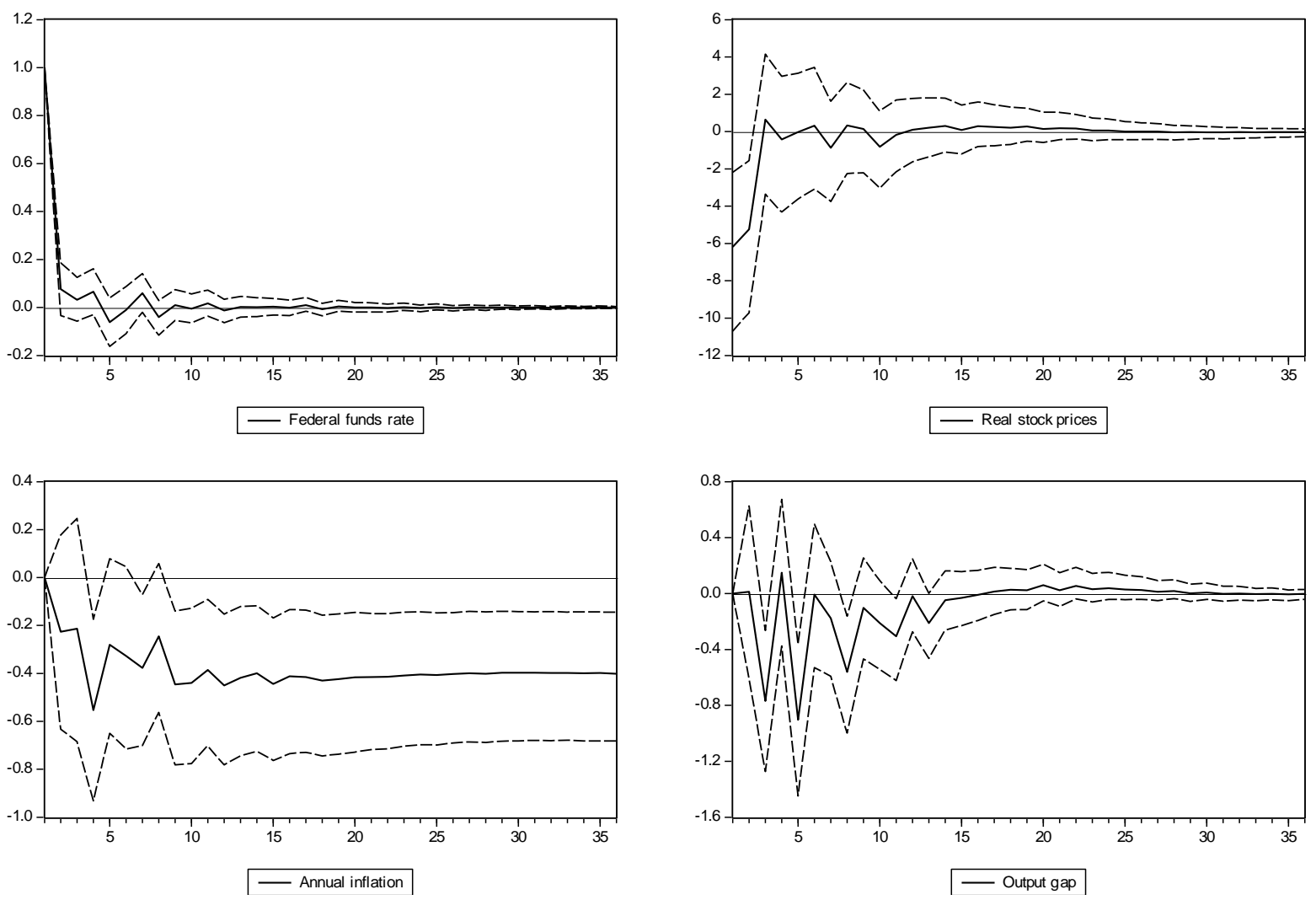

Notes: This figure plots the impulse response (solid line) of the federal funds rate, output gap, annual inflation, and real stock prices at the market level (S\&P500) following a 1-percentage-point contractionary monetary policy shock. The SVAR model is estimated over the sample period 1994:2 - 2007:7 including 6 lags. The state vector contains the first difference (lagged) in annual change of leading economic indicator $\left(\Delta l e a d^{a}{ }_{t-1}\right)$, the output gap $\left(\operatorname{gap}_{t}\right)$, the first difference in annual inflation $\left(\Delta \pi_{t}^{a}\right)$, monthly real stock market returns $\left(\Delta s p_{t}\right)$ and the effective federal funds rate $\left(i_{t}\right)$. A dummy variable that takes value of one in 2001:9 and zero otherwise and the 1-month federal funds futures contract rate (as of last business day of previous month) are included as exogenous variables. The dashed lines represent $68 \%$ Bayesian probability bands generated using Monte Carlo integration with 10000 draws as suggested by Doan (2015). 
Figure A2: Impulse responses to FFR shock: size-sorted portfolios - VAR(6)
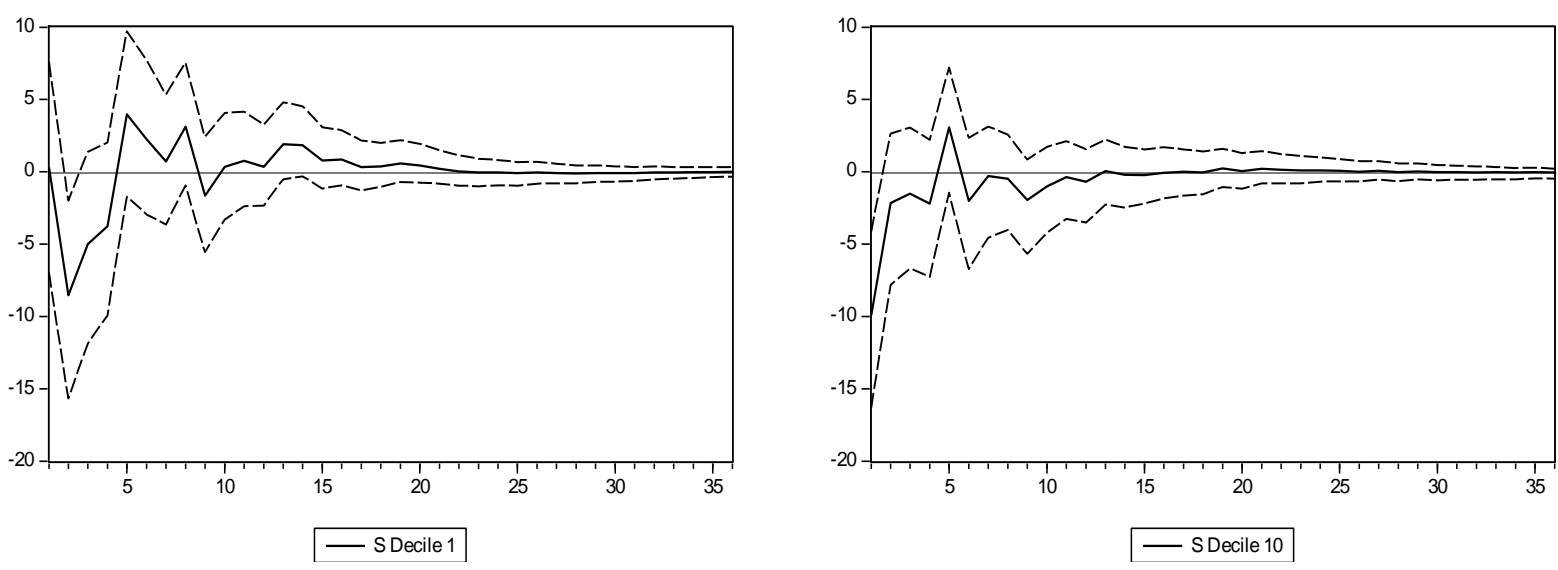

Notes: This figure plots the impulse response (solid line) of real stock prices at the portfolio level (Decile 1 and 10 of size-sorted portfolios) following a 1-percentage-point contractionary monetary policy shock. The SVAR model is estimated for each size decile portfolio over the sample period 1994:2 - 2007:7 including 6 lags. The state vector contains the first difference (lagged) in annual change of leading economic indicator $\left(\Delta l e a d^{a} t-1\right)$, the output gap $\left(\mathrm{gap}_{t}\right)$, the first difference in annual inflation $\left(\Delta \pi_{t}^{a}\right)$, monthly real stock portfolio returns $\left(\Delta s p_{t}\right)$ and the effective federal funds rate $\left(i_{t}\right)$. A dummy variable that takes value of one in 2001:9 and zero otherwise and the 1-month federal funds futures contract rate (as of last business day of previous month) are included as exogenous variables. The dashed lines represent $68 \%$ Bayesian probability bands generated using Monte Carlo integration with 10000 draws as suggested by Doan (2015). 


\section{Figure A3: Impulse responses to FFR shock - extended sample period}
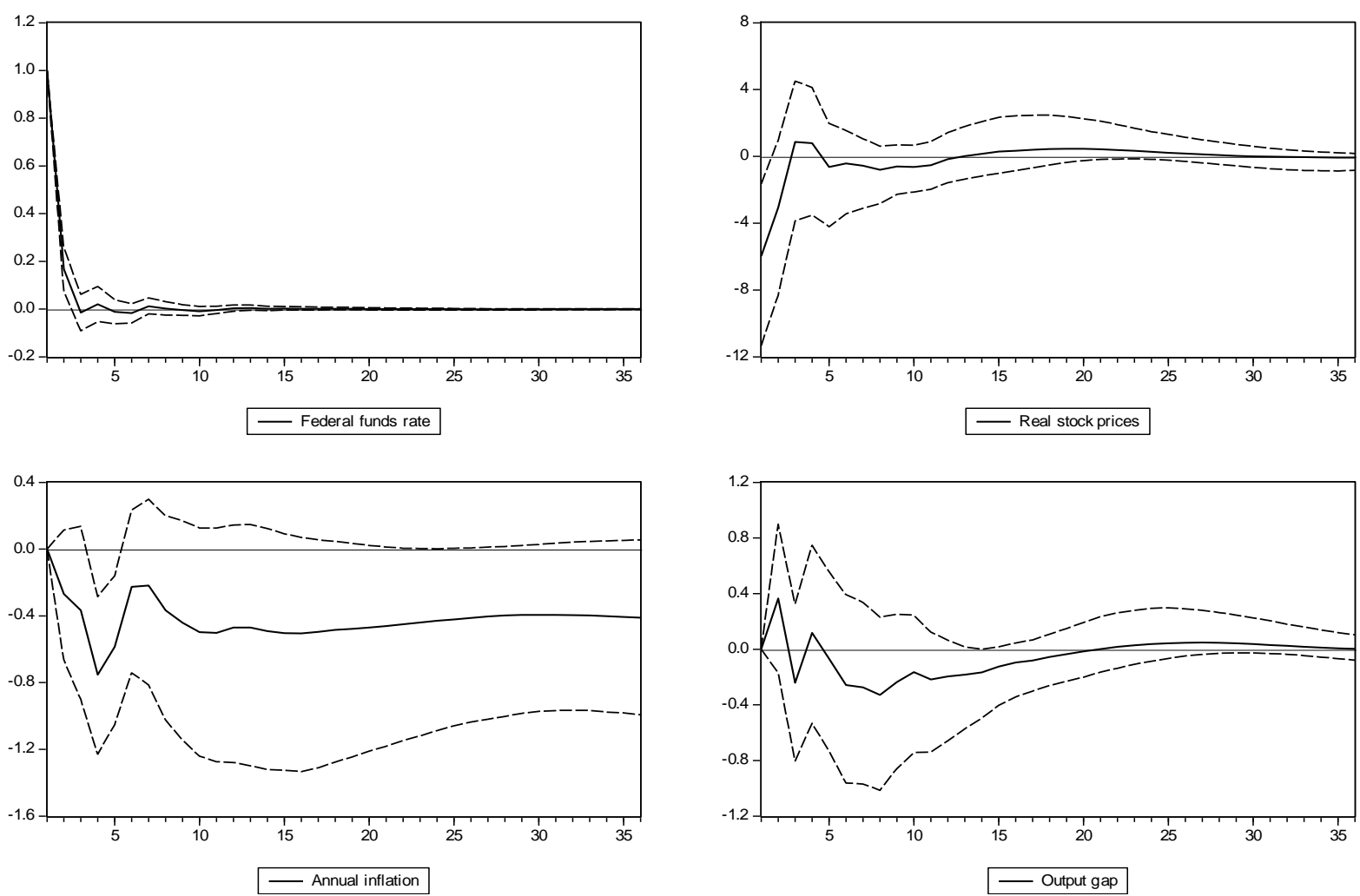

Notes: This figure plots the impulse response (solid line) of the federal funds rate, output gap, annual inflation, and real stock prices at the market level (S\&P500) following a 1-percentage-point contractionary monetary policy shock. The SVAR model is estimated over the sample period 1994:2 - 2008:12 including 4 lags. The state vector contains the first difference (lagged) in annual change of leading economic indicator $\left(\Delta l e a d^{a}{ }_{t-1}\right)$, the output gap $\left(\operatorname{gap}_{t}\right)$, the first difference in annual inflation $\left(\Delta \pi_{t}^{a}\right)$, monthly real stock market returns $\left(\Delta s p_{t}\right)$ and the effective federal funds rate $\left(i_{t}\right)$. Dummy variables that take value of one in 2001:9, 2008:9 and 2008:10 and zero otherwise, and the 1-month federal funds futures contract rate (as of last business day of previous month) are included as exogenous variables. The dashed lines represent $68 \%$ Bayesian probability bands generated using Monte Carlo integration with 10000 draws as suggested by Doan (2015). 
Figure A4: Impulse responses to FFR shock: size-sorted portfolios - extended sample period
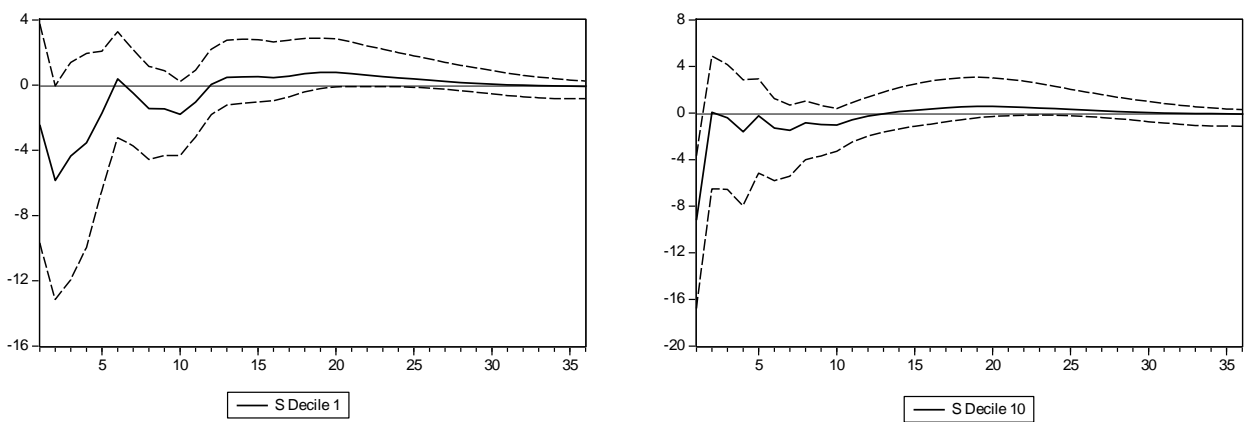

Notes: This figure plots the impulse response (solid line) of real stock prices at the portfolio level (Decile 1 and 10 of size-sorted portfolios) following a 1-percentage-point contractionary monetary policy shock. The SVAR model is estimated for each size decile portfolio over the sample period 1994:2 - 2008:12 including 4 lags. The state vector contains the first difference (lagged) in annual change of leading economic indicator $\left(\Delta l e a d^{a}{ }_{t-1}\right)$, the output gap $\left(\mathrm{gap}_{t}\right)$, the first difference in annual inflation $\left(\Delta \pi_{t}^{a}\right)$, monthly real stock portfolio returns $\left(\Delta s p_{t}\right)$ and the effective federal funds rate $\left(i_{t}\right)$. Dummy variables that take value of one in 2001:9, 2008:9 and 2008:10 and zero otherwise, and the 1-month federal funds futures contract rate (as of last business day of previous month) are included as exogenous variables. The dashed lines represent $68 \%$ Bayesian probability bands generated using Monte Carlo integration with 10000 draws as suggested by Doan (2015). 


\section{Figure A5: Impulse responses to FFR shock: size-sorted portfolios - quintiles}
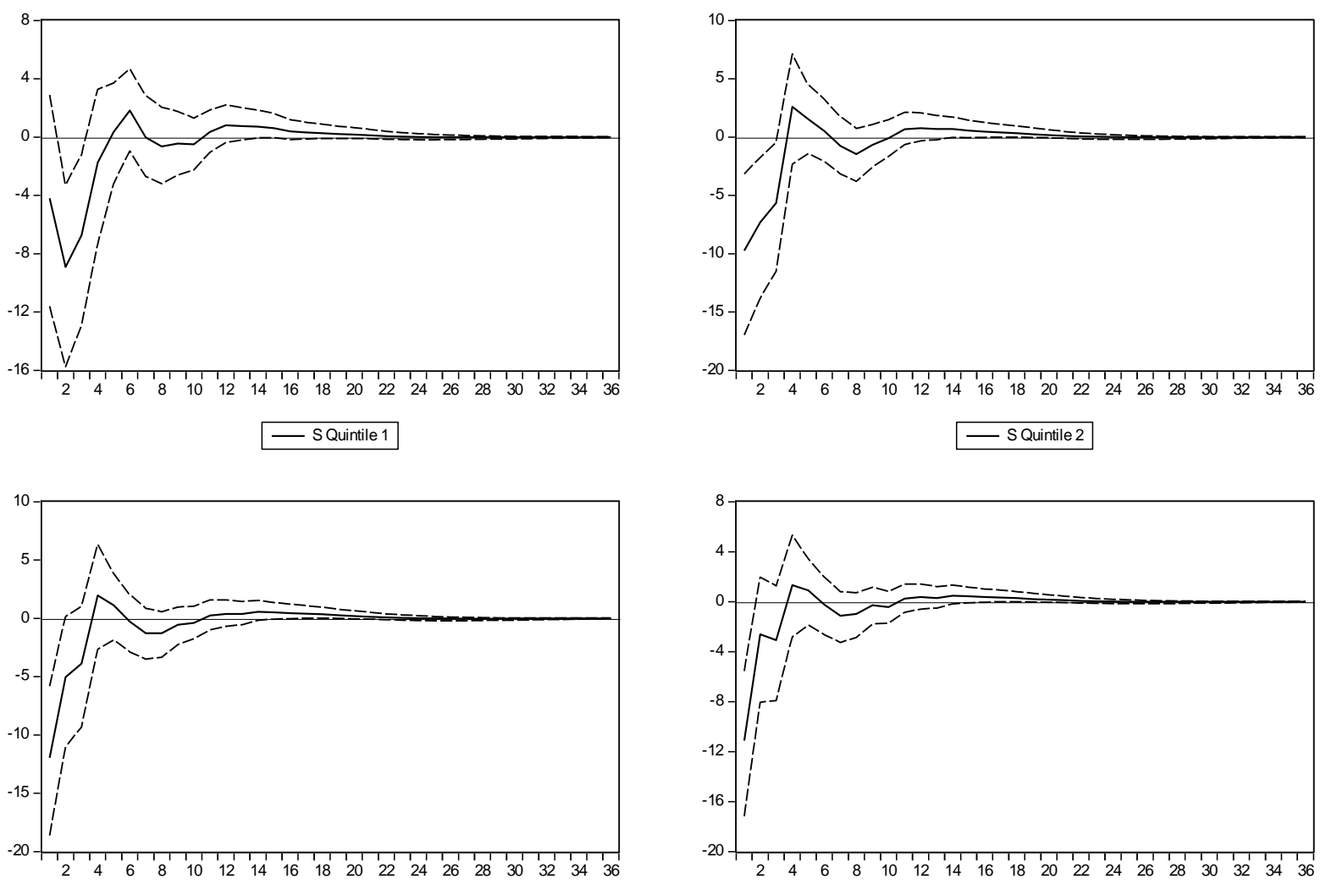

- S Quintile 3
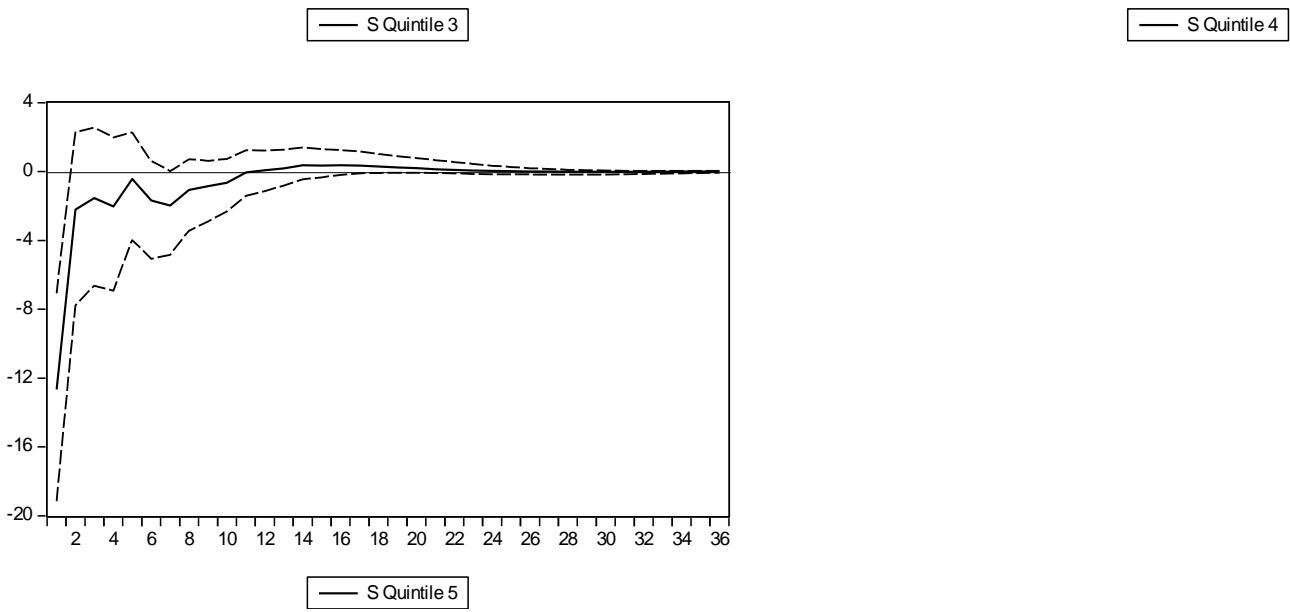

Notes: This figure plots the impulse response (solid line) of real stock prices at the portfolio level (5 size-sorted portfolios) following a 1-percentage-point contractionary monetary policy shock. The SVAR model is estimated for each size decile portfolio over the sample period 1994:2 - 2007:7 including 4 lags. The state vector contains the first difference (lagged) in annual change of leading economic indicator $\left(\Delta l e a d^{a}{ }_{t-1}\right)$, the output gap $\left(\operatorname{gap}_{t}\right)$, the first difference in annual inflation $\left(\Delta \pi_{t}^{a}\right)$, monthly real stock portfolio returns $\left(\Delta s p_{t}\right)$ and the effective federal funds rate $\left(i_{t}\right)$. A dummy variable that takes value of one in 2001:9 and zero otherwise and the 1-month federal funds futures contract rate (as of last business day of previous month) are included as exogenous variables. The dashed lines represent 68\% Bayesian probability bands generated using Monte Carlo integration with 10000 draws as suggested by Doan (2015). 
Figure B1. Output gap measures based on HP filter and quadratic trend

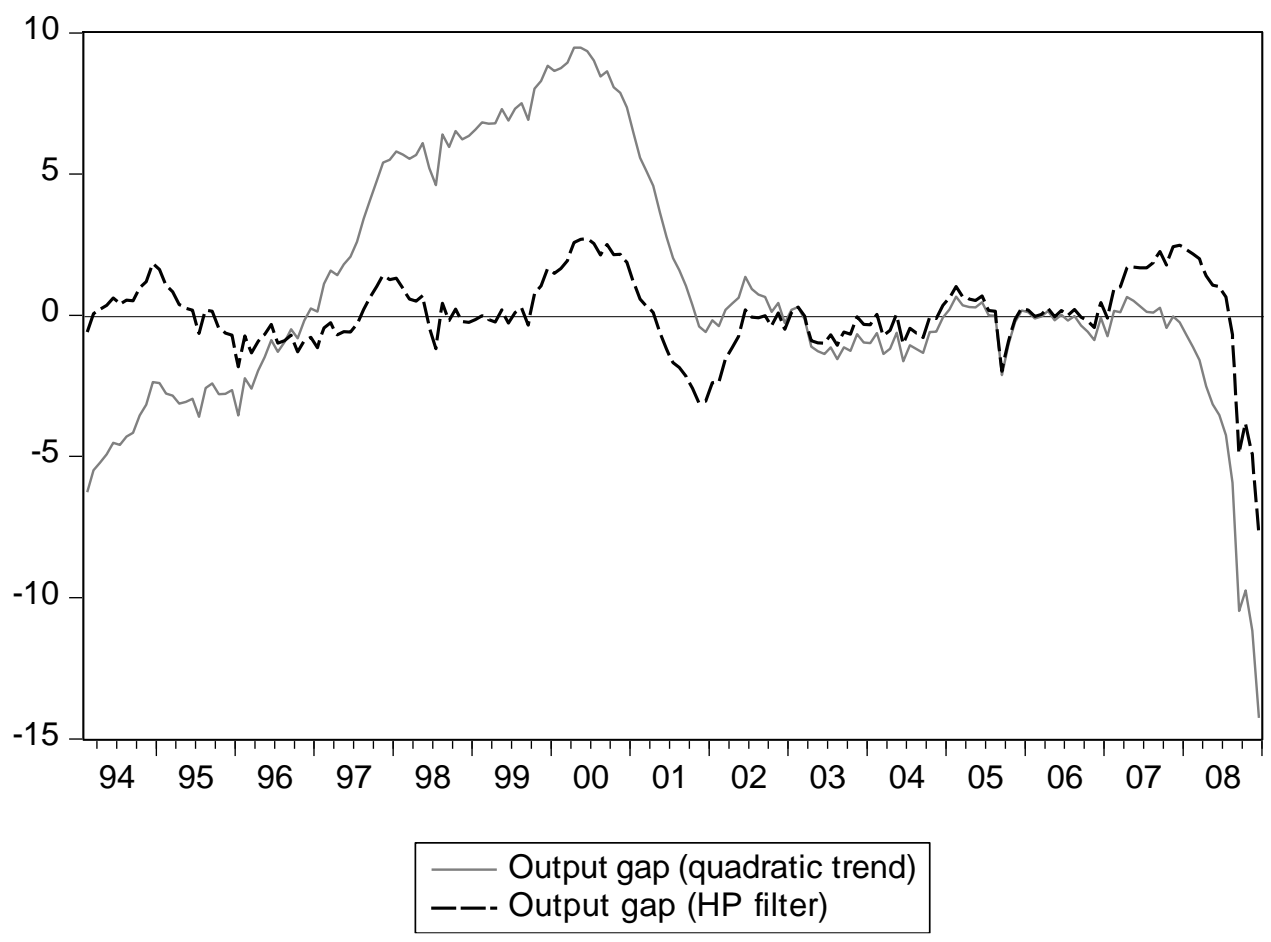

Notes: This figure plots the output gap measure obtained using quadratic de-trending method (solid line) together with the output gap measure based on HP filter (dashed line) over the sample period 1994:2 - 2008:12. 


\section{Figure B2. VAR variables}

Composite leading indicator (annual \% change)

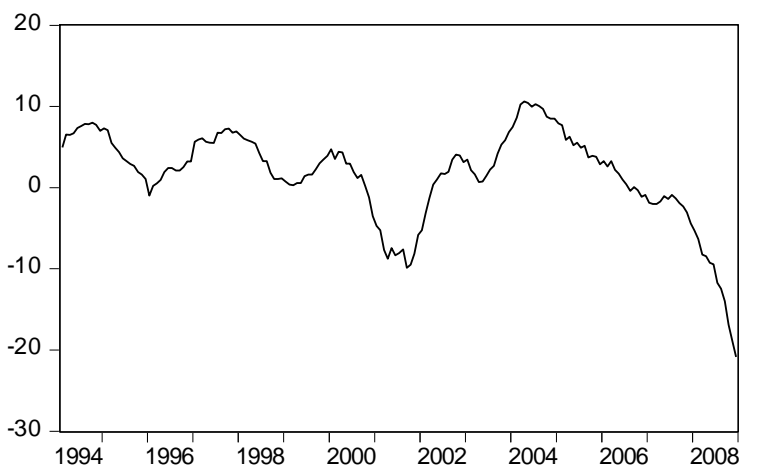

Inflation (annual \% change)

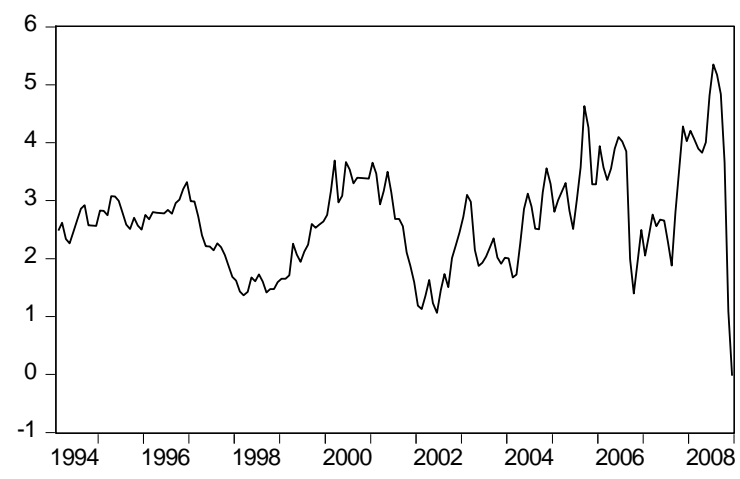

Effective federal funds rate

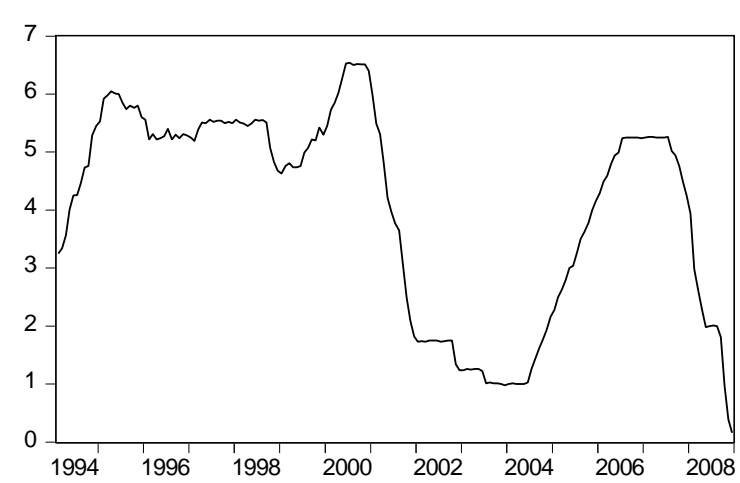

Output gap

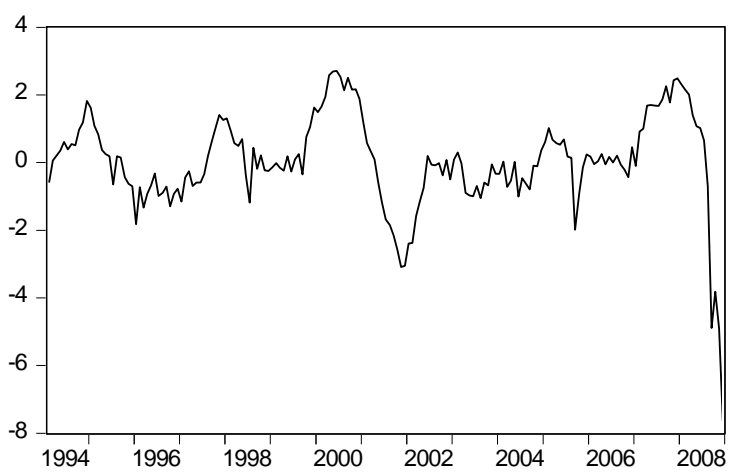

Real stock market returns (\% per month)

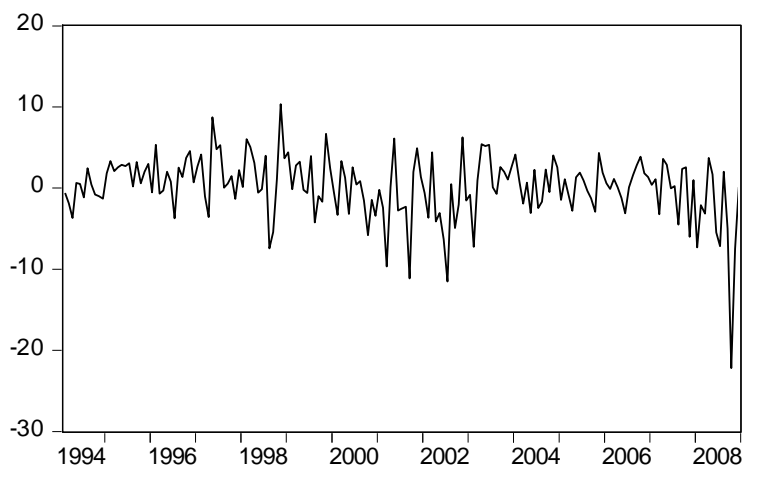

1-month federal funds futures rate

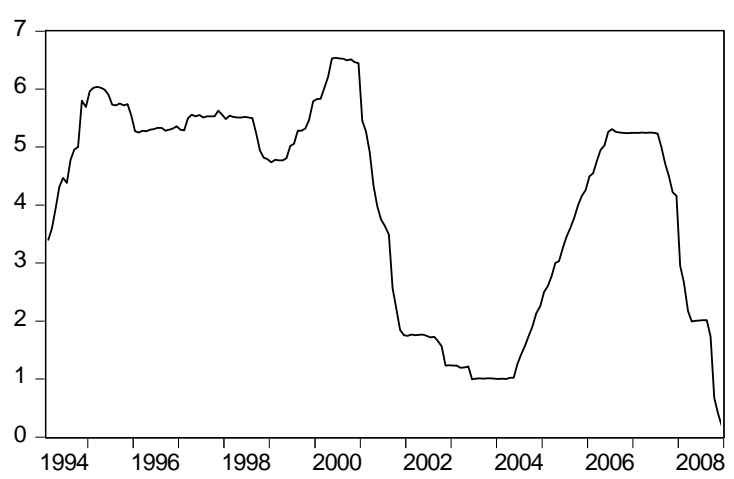

Notes: This figure plots the time series, used in the VAR estimation with respect to the stock market analysis, over the sample period 1994:2 - 2008:12: annual percentage change of leading economic indicator $\left(\right.$ lead $\left._{t}{ }_{t}\right)$, output gap $\left(g a p_{t}\right)$, annual inflation $\left(\pi^{a}\right)$, monthly real stock market returns $\left(\Delta s p_{t}\right)$, effective federal funds rate $\left(i_{t}\right)$ and 1-month federal funds futures contract rate $\left(f f f r_{t}\right)$. 
Figure B3. Real stock returns on size-sorted portfolios

S Decile 1

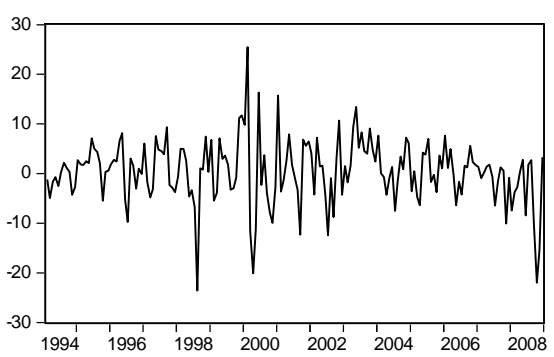

S Decile 3

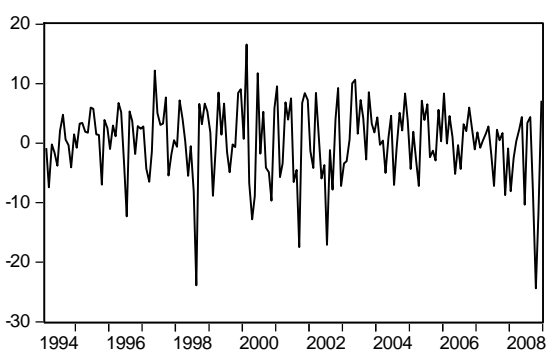

S Decile 5

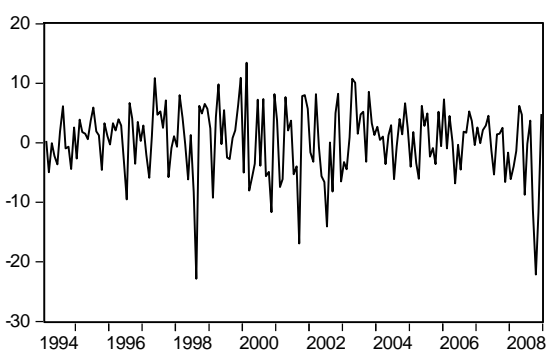

S Decile 7

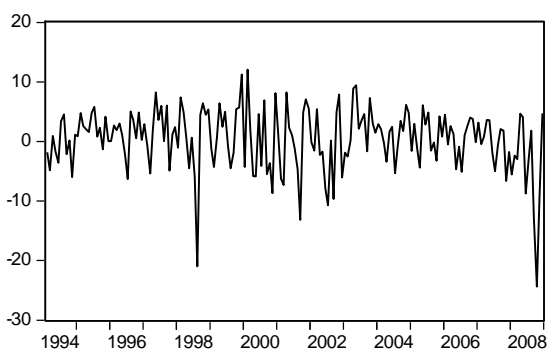

S Decile 9

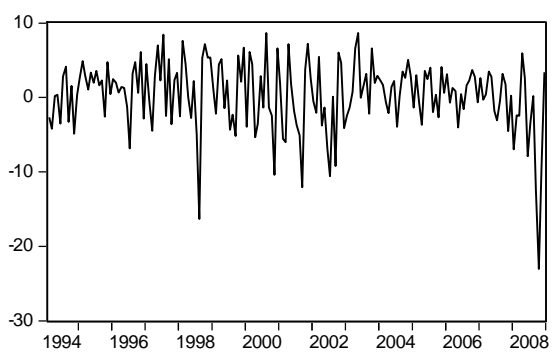

S Decile 2

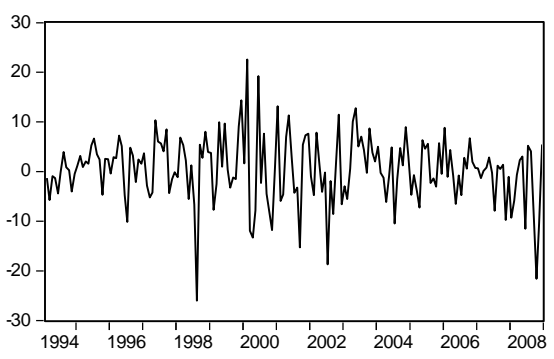

S Decile 4

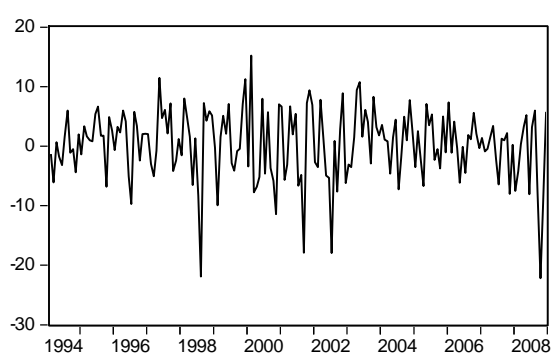

S Decile 6

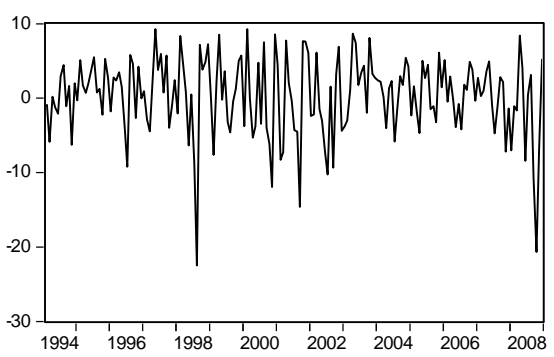

S Decile 8

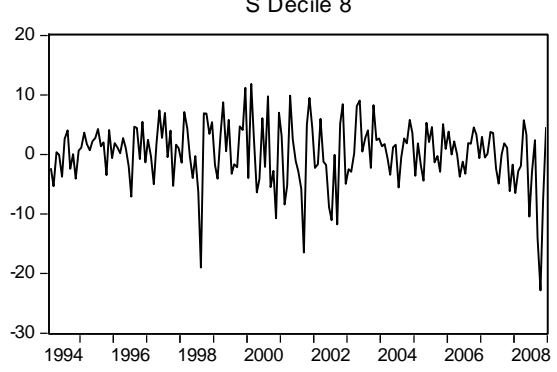

S Decile 10

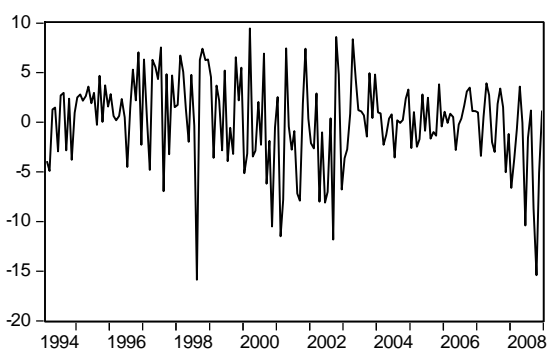

Notes: This figure plots the time series of monthly real stock returns $\left(\Delta s p_{t}\right)$ for ten size-sorted portfolios (deciles) over the sample period 1994:2 - 2008:12. 